\title{
1 Flow pattern evolution of the last British Ice Sheet
}

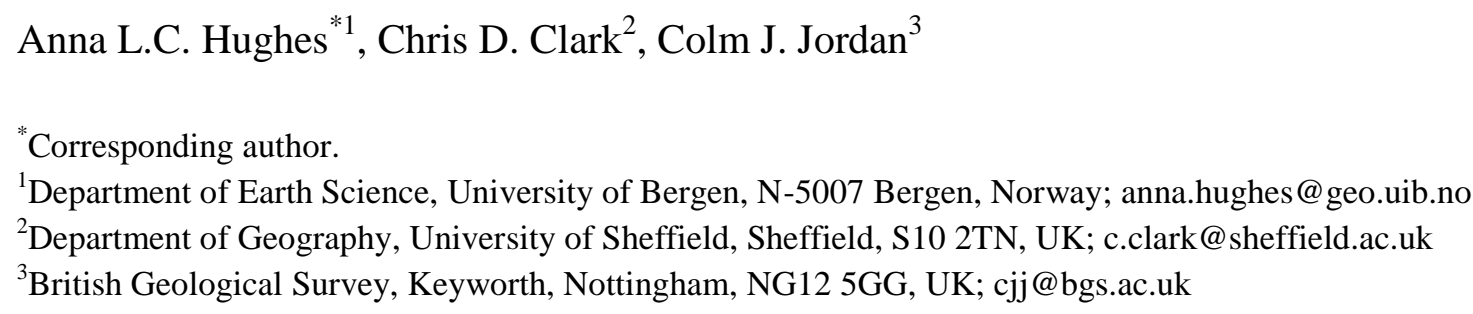

\section{Abstract}

We present a 10-stage reconstruction of the evolution in ice-flow patterns of the last British Ice Sheet from build-up to demise derived from geomorphological evidence. 100 flowsets identified in the subglacial bedform record (drumlins, mega-scale glacial lineations, and ribbed moraine) are combined with ancillary evidence (erratic-transport paths, absolute dates and a semi-independently reconstructed retreat pattern) to define flow patterns, ice divides and ice-sheet margins during buildup, maximum glaciation and retreat. Overprinting and cross-cutting of landform assemblages are used to define the relative chronology of flow patterns and a tentative absolute chronology is presented based on a collation of available dates for ice advance and retreat. The ice-flow configuration of the last British Ice Sheet was not static. Some ice divides were remarkably stable, persisting through multiple stages of the ice-sheet evolution, whereas others were transient features existing for a short time and/or shifting in position $10 \mathrm{~s} \mathrm{~km}$. The 10 reconstructed stages of ice-sheet geometry capture two main modes of operation; first as an integrated ice sheet with a broadly N-S orientated ice divide, and second as a multi-domed ice sheet orientated parallel with the shelf edge. A thick integrated ice sheet developed as ice expanded out of source areas in Scotland to envelop southerly ice caps in northern England and Wales, and connect with the Irish Ice Sheet to the west and the Scandinavian Ice Sheet across the North Sea. Following break-up of ice over the North Sea, ice streaming probably drove mass loss and ice-sheet thinning to create a more complex divide structure, where ice-flow patterns were largely controlled by the form of the underlying topography. Ice surface lowering occurred before separation of, and retreat to, multiple ice centres centred over high ground. We consider this 10-stage reconstruction of the evolution in ice-sheet configuration to be the simplest palaeo-glaciological interpretation of the flowsets identified from the geomorphological record and their relative timing. This empirically-based reconstruction of flowpattern geometry provides a framework for more detailed local and regional studies and numerical modelling to provide robust explanations of the observed changes in ice-sheet structure in terms of climate and glacial dynamics. As a minimum, numerical model outputs should be able to reproduce the identified flowset patterns in space and satisfy their chronological order.

\section{Introduction}

Ice-sheet reconstruction aims to determine the past size, form and evolution of palaeo-ice sheets in order to give time-constrained estimates of former ice-sheet volume, extent and form, and advance 
and retreat rates. Such information is critical to improve and constrain ice-sheet modelling efforts and understanding of ice-sheet behaviour over long timescales. Deciphering the evolution in icesheet geometry as determined by the ice-flow pattern configuration is central to this endeavour. Evidence-based reconstructions of flow-pattern dynamics locate the fastest (ice streams) and identify the highest (ice divides) parts of the ice sheet, and how these changed over time. Using such empirical reconstructions we can derive estimates of ice-sheet thickness and identify the location and timing of ice-stream operation and thus likely calving fronts, which can be compared with climatic and ocean changes during the last glaciation. Empirical reconstructions are also a test for numerical ice sheet models (e.g. Hubbard et al., 2009) that attempt to explain the controlling glacial and climatic dynamics. Located on the edge of the North Atlantic and at the fringes of the Eurasian Ice Sheet complex the last British Ice Sheet (BIS) and its counterpart the Irish Ice Sheet potentially have a great deal to reveal concerning ice sheet-ocean-climate interactions. Even at its largest extent, the combined British-Irish Ice Sheet was relatively small (comprising $\sim 2.5 \mathrm{~m}$ Sea Level Equivalent, Clark et al., 2012) with a predominantly marine-based margin but was connected at times to the larger Scandinavian Ice Sheet across the North Sea (Graham et al. 2007; Sejrup et al. 1994). The ice-rafted debris (IRD) record from the surrounding continental shelf is indicative of persistent instability and continual readjustment of the ice sheet (e.g. Peck et al., 2006), which has also been indicated by numerical modelling (Hubbard et al., 2009).

The general structure of ice-flow patterns across the British Isles was first synthesised from recorded striations, inferred erratic transport paths, till lithological properties and mapped streamlined-bedrock features at the turn of the twentieth century (Geikie, 1894; Wright, 1914, Charlesworth, 1957) (Fig. 1a). Since, there have been few attempts to reconstruct ice-flow patterns at the national or ice-sheet scale. Superimposed, cross-cutting drumlin patterns and variable size distributions are exhibited by many of Britain's drumlin fields indicative of changes in the configuration of the ice sheet and subglacial processes and/or environments (Rose and Letzer, 1977; Letzer, 1987; Mitchell, 1994, 2007; Livingstone et al. 2008; Hughes et al. 2010). Several recent local-regional scale reconstructions have provided tantalising glimpses into the ice-sheet evolution noting considerable complexity and variation in time for discrete sectors of the BIS (e.g. Mitchell, 1994; Salt and Evans, 2005; Jansson and Glasser, 2004; Bradwell et al., 2008a; Finlayson et al. 2010, 2014; Livingstone et al. 2010a, 2012). These studies demonstrate that individual ice divides of the last BIS were spatially and temporally variable, and that their dominance varied over time.

In this paper we use countrywide mapping of the terrestrial subglacial bedform record (Hughes et al. 2010; Hughes, 2009) supplemented with evidence from the marine record (e.g. Stoker and Bradwell, 2005; Bradwell et al. 2007, 2008a; Graham et al. 2007, 2010; Stoker et al. 2009; Howe et al. 2012) to synthesise flow-pattern information across the former ice-sheet bed and reconstruct the ice-sheet scale flow-pattern evolution of the last BIS in its entirety. We focus on the British record, but will necessarily make reference to the Irish Ice Sheet, and implications for the combined British-Irish Ice Sheet. We build on the pattern of ice-sheet margin-retreat reconstructed by Clark et al. (2012) by extending the reconstruction to include changes to the internal ice-sheet flow-pattern geometry, both during retreat and the more challenging ice-sheet build-up phases. 


\section{Approach: palaeoglacial inversion}

We rely on our interpretation of the landform record in terms of ice-flow vectors (flowsets), augmented with data from the published literature, to produce a reconstruction via a logical methodology and set of interpretative assumptions (e.g. Kleman et al. 2006; Greenwood and Clark, $2009 \mathrm{ab})$. The reconstruction is principally geomorphological and we aim to produce the simplest model that best explains most of the evidence and captures the characteristics of the ice sheet as a whole. As with a reconstruction produced by numerical modelling, the final result may conflict with some of the field evidence and serves to highlight sites and topics for further investigation. The theoretical basis for this approach has been outlined in a series of preceding papers (Kleman and Borgström, 1996; Kleman et al. 1997; Clark, 1997; Clark et al. 2000; Clark and Meehan, 2001; De Angelis and Kleman, 2005, 2007; Kleman et al. 2006; Greenwood and Clark 2009ab; Trommelen et al. 2012).

\subsection{Glacial Maps}

Our starting point is a comprehensive map of glacial landforms covering the terrestrial part of the former ice-sheet bed (Hughes et al. 2010). We use what we believe is a near-complete map of the subglacial bedform record of Britain (including drumlins, Mega-Scale Glacial Lineations (MSGL), crag and tails and ribbed moraine), produced by systematic remote mapping of the whole onshore glaciated area from a high-resolution digital surface model (NextMap Britain DSM; $5 \mathrm{~m}$ horizontal resolution) as the basis for the reconstruction of flow patterns. Break-of-slope digital capture of each landform was conducted at a scale of 1:10000 or less. Full details of the mapping process including quality control procedures are given in Hughes et al. (2010). Maps of moraine, esker, meltwater channel and streamlined bedrock distributions derived from the same DSM source (Hughes, 2009; Benn and Evans, 2010, Fig. 12.96; Clark et al. 2012, Figs. 4,5,7,8) and published records of inferred erratic-transport paths as collated in the BRITICE database (Clark et al. 2004) are integrated to inform flowset interpretation (Section 2.2.2) and provide independent geometric information (Fig. 4). To our knowledge a comprehensive map of striations (e.g. Smith and Knight, 2011) has not been compiled for Britain, and we do not make reference to recorded instances of striations. In mainland Britain striations tend to record local-regional flow patterns conforming to undulations in the local topography (Evans et al. 2005) rather than the large-scale ice-flow geometry, which is the focus of this work.

\subsection{Flowsets}

\subsubsection{Flowset building}

The first interpretative stage of the inversion approach is a process of rationalisation which reduces the multifarious record contained within the glacial map into a manageable volume of information by grouping landforms into summary assemblages or flowsets. Flowsets are identified by inspection of the spatial arrangement of landforms with consideration of their morphometry, i.e. length, elongation ratio (length/width), parallel conformity, spacing, and orientation (Fig. 2) (Greenwood and Clark, 2009a).

We focus on the lineation record where each flowset defines a coherent group of drumlins, crag and tails and/or MSGL representing a discrete phase of ice flow (e.g. Boulton and Clark, 1990; Kleman 
133 and Borgström, 1996; Clark, 1997; Kleman et al. 1997; Clark, 1999; Clark et al. 2000; Clark and 134 Meehan, 2001; DeAngelis and Kleman, 2007; Greenwood and Clark, 2009a). Instances of ribbed 135 moraine are relatively rare in Britain (Hughes et al. 2010), and ribbed moraine assemblages are interpreted simply as ridges formed perpendicular to ice flow (e.g. Greenwood and Clark, 2009a) rather than indicative of specific bed conditions (e.g. Trommelen et al. 2012; Dunlop et al. 2008).

Each flowset is classified in terms of the glaciological and temporal context of formation. landform associations, e.g. with eskers and/or meltwater channels, using templates grounded in theoretical concepts of landform generation (Table 1) (Kleman and Borgström, 1996; Clark, 1999; Clark et al. 2000; Kleman et al. 2006; Greenwood and Clark, 2009a; Stokes and Clark, 1999). The primary distinction is between isochronous flowsets that represent a single flow event at a point in time (but which may have lasted for some time under a stable ice-sheet geometry) and smudged or time-transgressive (TT) imprints produced by two or more flow events which are too subtly different to be clearly separated. Flowsets were organised into a relative age stack by careful examination of superimposition relationships of the constituent bedforms (Table 2) using the highresolution $(5 \mathrm{~m})$ digital elevation model used for mapping.

\subsection{Reconstruction process}

\section{2.3.1 Reconstruction ingredients}

The lineation flowsets and relative age order are the primary pieces of evidence used in the reconstruction presented (Fig. 3, Tables 2 and S1). Generalised summaries of erratic transport paths contained within the BRITICE database (Clark et al. 2004) and mapping of streamlined bedrock (Hughes, 2009) are used as further support for and to supplement reconstructed ice-sheet flow patterns (Fig. 5b). Streamlined bedrock and erratic distribution are regarded as second order indicators of ice-flow patterns as they are likely to be the result of multiple ice-flow events, and possibly the cumulative effect of several cycles of ice-sheet growth and retreat and no interpretations are based on these indicators alone. As our glacial mapping is limited to the presentday coastal boundary (Hughes et al. 2010; Hughes, 2009), we use published offshore evidence to aid our reconstruction beyond the coastline. Where available, this includes moraines (e.g. Bradwell et al. 2008a; Clark et al. 2012) and subglacial landforms (e.g. Graham et al. 2007, 2009; van Landeghem et al. 2009). We use the retreat pattern of the last British-Irish Ice Sheet (Clark et al. 2012), reconstructed from maps of ice-marginal features (moraines, eskers, meltwater channels, and glaciofluvial deposits) and flowsets classified as TT retreat type $(n=32)$ to define margin positions during deglaciation and to tease out additional flowsets that were formed during retreat (Section 2.3.3, Fig. 5a). Timing of events is based on a database of published absolute chronological information for the build-up and deglaciation of the last British-Irish Ice Sheet (Hughes et al. 2011) which has already been used to date the pattern of marginal retreat (27-15 ka, Clark et al. 2012). We use an updated version of the database with a census date of 1 May 2012 (http://www.sheffield.ac.uk/geography/staff/clark_chris/britice-chrono) (Fig. 5c).

\subsubsection{Inversion rules}

The interpretative process of inversion is subjective and different researchers may generate slightly different interpretations from the same evidence. For this reason we outline the interpretative stages 
involved and we make the subglacial bedform map (Hughes et al. 2010) and flowsets available for scrutiny (Figs. 3, S1; Table S1). The following rules or assumptions inform our organisation of flowsets into scenarios of ice-sheet geometry, and direct the choice of alternative scenarios where they arise (after Greenwood and Clark 2009b).

1. Symmetry. Ice sheet geometry will be similar to modern ice sheets, i.e. tend towards a broadly symmetrical plan form, with ice flow radiating out from divide locations, and comprising at least one principle ice divide with the possibility of subsidiary divides branching off from the main divide. Saddles will occur between connected divides.

2. False divides. Regions beneath divides are zones of landscape preservation. Divides must therefore be upstream of a landform imprint and we must invoke divide migration when flow patterns diverge in close proximity.

3. Multi-temporal record. We must invoke changes in configuration where more than one imprint is superimposed and obey the relative chronology as defined by superimposition/stratigraphic relationships.

4. Extent. Ice is not constrained to the present day terrestrial landmass. Ice is allowed to extend out to the continental shelf in the North and West, to the Scilly Isles in the southwest, and the southern drift limit in England when indicated by flow patterns.

5. Avoid preconceived ideas. Allow the reconstruction to develop as the evidence dictates.

6. Minimum complexity. Use the minimum number of divides to satisfy data. Attempt the simplest solution, only conflicting evidence leads to a new configuration.

7. Ice streams are likely to have existed, and been integral to the ice sheet geometry (Bennett, 2003). They are presumed capable of driving rapid configuration changes. They may also briefly cause asymmetric ice sheet form.

\subsubsection{Reconstruction Process}

The preserved record is fragmentary and incomplete by nature and so a degree of interpolation is required to reconstruct plausible overall geometries from the identified flowsets. Potential flowset groupings are assessed and rejected/accepted on the basis of spatial conformability and adherence to the above rules (Section 2.3.2). The temporal component of flowset generation (isochronous or time-transgressive) must also be satisfied. The process is iterative, and proceeds by continual reassessment and modification as decisions are made and checked against the rules and glaciological plausibility. Where it is not possible to determine the relative-age relationships between flowsets a greater number of permutations can occur. In Britain, highly variable topography over short distances means that there are many small discrete flowsets that do not overlap (Fig. 3), and therefore had no relative age control (Table 2). This necessitated additional and new approaches to reduce complexity and explore possible configuration geometries to reduce the potential number of permissible permutations and connect fragmented records together (e.g. Trommelen et al. 2012). Here, a regional approach was undertaken in the first instance where relative age constraints were good (e.g. Figs. 5, 6), followed by analysis to distil the larger structural elements of the ice-sheet-scale form to tie phases of the regional reconstructions together. Figs. 5 and 6 show the regional scenarios for NE England and northern Scotland as illustrative examples and to show in more detail the interpretative decisions behind our final reconstruction (Section 3.2; Fig. 8). 
To identify tie-points that could be used to integrate the spatially disparate regional sequences of information into plausible ice sheet scale geometries, we considered: i) the relationship between topography and flowset size, ii) the location and size of ice stream signatures, and iii) coherence with the retreat pattern derived from marginal landforms and TT retreat flowsets (Clark et al. 2012; Fig. 7). This analysis created a synthesis framework from which we could tease out those flow patterns from each region belonging to similar phases of the ice sheet history and link the regional scenarios together. An inversion model of the neighbouring Irish Ice Sheet (Greenwood and Clark, 2009b) was used as a final extra check to decide between alternative scenarios.

We interpret flowsets that disregard topography as a record of the pre-deglacial ice sheet configurations and as providing a glimpse of ice-sheet geometry during maximum extent. We assume that these pre-deglacial flowsets (where there is no contradictory evidence and the resultant configuration appears plausible) to belong to broadly the same ice-sheet configurations and act as tie-points for combining the regional reconstruction sequences. The majority of the remaining flowsets (where there is no contradictory evidence and the resultant configuration appears plausible) are regarded as documenting the changing geometry of the ice sheet during deglaciation. This interpretation is supported by the fact that flowsets that disregard topography are generally the oldest in the relative age stack (Table 2) and most of the remaining flowsets are consistent with the

\section{Flow patterns and evolution of the last British Ice Sheet}

\subsection{Flowsets of the last British Ice Sheet (Fig. 3, Fig. S1, Table S1)}

We identify 100 lineation flowsets in the British subglacial-landform record (Fig. 3; Table S1). Approximately one third of the flowsets are classified as isochronous $(n=37)$. Smudged (timetransgressive) imprints are not restricted to deglacial flow events (e.g. Clark et al. 2000); 32 are interpreted to have formed behind a retreating ice margin (TT retreat), 14 record increasing/decreasing effect of topography (TT thinning/thickening) and 8 are interpreted as the result of a shift in the ice divide location (TT flowline). 10 flowsets exhibit characteristics of ice streams. We have confidence in 85 flowset classifications. There are 15 flowsets, (generally those 
composed of only a handful of landforms or within highly complex zones) that cannot be classified (Table S1).

Flowsets with topographic congruence are generally the youngest in the relative age stack and collectively require multiple ice-divide locations over most areas of high ground (Fig. 7b; Tables 2; $\mathrm{S} 1$ ). Flowsets that disregard topography are located roughly east and west of an imaginary line running approximately north-south, require ice centres on both high and low ground and are generally the oldest in the relative age stack (Fig 7a, Tables 2; S1). In addition to the 32 TT retreat type flowsets, 28 flowsets of isochronous, TT flowline and TT thinning/thickening type document flow patterns that conform to the reconstructed pattern of retreat and therefore are likely representative of the changing ice-flow geometry during deglaciation (Fig. 7c).

Ice streams have been identified or postulated in The Minch (Stoker and Bradwell, 2005), Witch Ground (Graham et al. 2007), Strathmore (Golledge and Stoker, 2006), Tweed (Everest et al. 2005), Tyne Gap (Livingstone et al. 2010a; Evans et al. 2009), eastern England (North Sea Lobe, Evans and Thompson, 2010; Boston et al. 2010, Davies et al. 2012; Roberts et al. 2013), Irish Sea (Evans and Ó Cofaigh, 2003; Roberts et al. 2007), North Channel (Greenwood and Clark, 2009b) and the Hebrides (Howe et al. 2012), Moray Firth (Merritt et al. 1995) and Firth of Forth (Fig. 7d). We identify signatures of most of the terrestrially-based ice streams in our flowsets (Table $S 1 ; f_{s} 4, f_{s} 5$, $\left.f_{s} 6, f s 8, f s 10, f s 11, f s 18, f s 19, f s 51, f s 56, f s 99\right)$. On the basis of size and relative chronology it is possible to organise our ice-stream flowsets into groups representing at least two possible ice-flow configuration frameworks. One grouping (Minch- $f_{s} 4$, Strathmore 1- $f s 51$, North Channel $-f s 8$, Irish Sea $\left.-f_{s} 18\right)$ is proposed to occur during maximum extent when the ice sheet was confluent with ice in the North Sea and reached the continental shelf edge. During maximum stages ice streams occur at the junctions between ice masses, e.g. Scottish and Irish ice in the North Channel and mainland Scottish and Outer Hebrides ice in the Minch, and there must be an ice divide running broadly N-S over Highland Scotland and a connection with the Irish Ice Sheet. Fs51 (Strathmore 1) is tentatively correlated with the Witch Ground Ice Stream (Graham et al. 2007). A second group of ice streams (Tweed $-f_{s} 10$, Strathmore $2-f_{s} 56$, Moray Firth $-f_{s} 6$, Forth $f_{s} 19$, Tyne Gap $f_{s} 11$ ) are all restricted to the onshore record, indicate topographic confinement, and suggest a more complex divide structure However, within the second group not all flowsets can be associated with the same stage. In compliance with the relative chronology we associate $f s 10, f s 56$ and $f s 6$ with the later (deglacial) and $f_{s} 19, f_{s} 11$ with the earlier (build-up) phases of ice sheet evolution.

\subsection{Flow pattern evolution of the last British Ice Sheet}

Following the rules and process outlined in Section 2 we present the simplest glaciologicallyplausible explanation of the preserved geomorphological record (Fig 8, Table 3).

\subsubsection{Stage 1}

The oldest flowsets in Scotland are large and topographically unconstrained and therefore necessitate a large ice cap centred on the Scottish Highlands ( $f s 7, f s 33, f s 2$; Tables 2 and 3 ). Grouping these flowsets together requires a main ice divide running along the NW Highlands and a secondary fork over the Grampian Mountains. Deflection of ice to north $(f s 33)$ and south $(f s 7)$ in the west is explained by the position of this secondary divide. Evidence is all on the eastern side of the ice sheet, the western side is inferred from rule of symmetry. East-west orientated ice flow over the 
Western Highlands is consistent with the generalised orientation of streamlined bedrock (e.g. Bradwell et al. 2008b) and erratic evidence (Clark et al. 2004) (Fig. 4b). A connection with an ice cap centred on the Outer Hebrides is inferred from the absence of erratic evidence for overriding of these islands by ice from mainland Scotland during the last glacial period. This necessitates deflection of ice around the islands and supports the development in later stages of ice streams along The Minch trough (Stoker and Bradwell, 2005) and south of the Hebrides (Howe et al. 2012). The orientation of $f s 2$ suggests no connection with ice cover over Shetland at this time, and we place the ice-sheet margin to the south of Orkney. Placement of the ice divide upstream of the flow pattern inscribed by $f s 2$ and $f s 7$ necessitates that the south-western margin is placed over the North Channel close to northern Irish coast by rule of symmetry. This stage occurs prior to (but sets up conditions for) an incursion of Scottish-sourced ice into Northern Ireland, the earliest stage (Stage I) reconstructed by Greenwood and Clark (2009b). It is possible that both the southern and northern margins were more extensive, and that ice masses had started to develop on high ground to the south and on Shetland but without adequate evidence to define their boundaries they are not marked on the maps.

\subsubsection{Stage 2}

Fs52 indicates ice flow from a source in western Scotland curving towards the east coast. We interpret this deflection as due to a competing ice source centred on the south-western Southern Uplands. South-westerly extrapolation of the northwest-southeast orientated ice flow of $f s 52$ from a source over the western Highlands and Islands of Scotland moving over the Firth of Clyde explains presence of shelly till in Ayrshire (Fig. 4b) and is consistent with the ice-flow direction inferred from the large area of ribbed moraine in the region ( $\mathrm{rm} 2$; Fig. 3 inset map). Fs 2 fits into Stages 2-4 suggesting relatively stable ice-flow directions in the northern sector, but we extend the northern and western margins further out onto the shelf to mirror the southerly expansion. Fs33 is classified as TT flowline type and shows a minor shift in flow pattern orientation which we infer as due to movement of the principal ice divide to the southwest, consistent with convergence with a Southern Uplands ice mass. We depict incursion into Ireland but the geometry is also consistent with connection to an Irish-sourced ice mass.

\subsubsection{Stage 3}

Deflection of ice around the Lake District and down the Vale of Eden to the east $\left(f_{s} 57\right)$ indicates further expansion of Scottish-sourced ice south and connection to a Lake District ice dome. We infer development of the Southern Upland ice dome into a secondary divide and a shift of the primary divide to the southeast. The connection between Highland and Southern Upland ice becomes centred over low ground. The position of $f_{s} 8$ implies an ice divide (or saddle) across the North Channel and we propose this flowset represents the vestigial terrestrial imprint of an ice stream draining the Irish and Scottish Ice Sheets towards the Barra Fan (North Channel Ice Stream) as also reconstructed by Greenwood and Clark (2009b). Both the size of the Barra Fan, the prominence of the bathymetric trough in the North Channel and sea-bed morphology lead us to suspect that this was an important ice flow path for the last BIS and likely formed a substantial ice stream network together with ice from Ireland (Barra Fan Ice Stream, Scourse et al. 2009; Dunlop et al. 2010) and northern Scotland (Hebrides Ice Stream, Howe et al. 2012). We maintain the secondary divide over northeast Scotland from the previous stage, which results in a shift to westeast orientated ice flow over central-eastern Scotland. An ice stream may have developed in the Moray Firth at this time, although we have no direct evidence for this. Although not depicted on 
352 Fig. 8 an ice cap on the Welsh uplands is inferred from subsequent stages. This configuration

353 corresponds to Stage II in Ireland as reconstructed by Greenwood and Clark (2009b).

$354 \quad 3.2 .4$ Stage 4

355 A major ice divide running broadly north-south from western Scotland to west of the Lake District

356 is inferred from evidence for major west-east ice flow across northern England and central Scotland

357 ( $\left.f_{s} 19, f_{s} 11, f_{s} 30\right)$. Secondary divides over eastern Scotland follow from the preceding stages and the

358 orientation of flow-lines. We infer development of the Irish Sea Ice Stream and strengthening of the

359 North Channel Ice Stream as ice is forced around the Irish Ice Sheet. Ice streams discharge into the

360 North Sea $\left(f_{s} 19, f_{s} 11\right)$. Both $f_{s} 19$ and $f s 11$ are classified as TT thinning/thickening type, which we

361 interpret as due to an increase in ice-surface elevation relative to the bed topography during a period

362 of stable W-E ice flow. As in the preceding stage this configuration would permit an ice stream in

363 the Moray Firth, but no explicit flowset is associated with this. Fs 19 is splayed at the coast

364 suggesting termination at a terrestrial ice margin and therefore this stage is placed before any

365 connection with the Scandinavian Ice Sheet in the North Sea. Smudging within $f s 2$ indicates a slight

366 shift in flow patterns to a south-north orientation over northern Scotland. We infer connection with

367 a substantial Welsh ice cap by this stage with an ice divide running broadly north-south $(f s 22)$ as

368 there is no evidence for invasion of Wales by the Irish Sea Ice Stream as it advances south. This and

369 Stage 5 correspond to Irish Stage IIIa/b (Greenwood and Clark, 2009b).

$370 \quad 3.2 .5 \quad$ Stage 5

371 Eastern flow patterns are diverted to the north $\left(f_{s 34}\right)$ and south $\left(f_{s} 13\right)$ and ice flow over Scotland

372 switches towards the north-northwest $\left(f_{s} 1\right)$ consistent with striae and erratic evidence (Sissons,

373 1967, Fig. 39; Figs. 6 and 4b). Ice flow orientated SE-NW overwhelms Shetland (fs59). We invoke

374 confluence with the Scandinavian Ice Sheet over the western North Sea (Sejrup et al. 1994) to

375 explain these 90 degree shifts in ice flow across the east of the country and the first major change in

376 ice-flow patterns in northern Scotland (Fig. 6). Marine sediments found in Caithness at the tip of

377 northeast Scotland support ice flow moving onshore from the south (Sissons, 1967, Fig. 39; Figs. 6

378 and 4b). North-south orientated ice flow patterns over the North Sea are derived from the orientation of MSGL attributed to the Witch Ground Ice Stream (Graham et al. 2007). These flow pattern changes show that the primary ice divide shifted $\sim 60 \mathrm{~km}$ south and switched from to a north-northwest to south-southeast alignment. Fs 9 over southwest Scotland is included here as is difficult to incorporate into other stages but could also be incorporated into Stage 4; $f s 9$ indicates a $\sim 50 \mathrm{~km}$ shift north of the connecting saddle/divide between Scotland and Ireland, consistent with advancement and increasing catchment size of the Irish Sea Ice Stream and reorganisation of ice flow over eastern Scotland. Growth of the Irish Sea Ice Stream catchment area reduces the catchment area and probably results in a decline in vigour of the North Channel Ice Stream (Greenwood and Clark, 2009b). A Welsh ice cap develops ( $f$ s22) and we extend the Irish Sea Ice Stream to the south as its catchment area increases around the Welsh ice cap ( $\left.f_{s} 17\right)$. The main ice divide over northern England shifts east as the Irish Sea Ice Stream develops, which was probably

$391 \quad 3.2 .6$ Stage 6

392 Ice flow over central-eastern Scotland switches to broadly west-east orientation $\left(f_{s} 51\right)$. Deflection of $f s 51$ to the north suggests maintenance of significant ice in the southern North Sea or a matching southerly flowing (and possibly surging) ice lobe along northern English coast (North Sea Lobe; Evans and Thompson, 2010; Boston et al. 2010) which would also be consistent in the preceding 
and following stages. The principle ice divide is pushed west and north to accommodate $f s 51$ and $f_{s} 18$ and southerly orientated ice flow over northwest England $\left(f_{s} 31\right)$ creating a new tripartite divide structure . This requires a return to west-east ice flow over northeast England and eastern Scotland. The secondary divide over eastern Scotland disappears and the centre of the ice sheet is shifted south. Ice streams operate in Strathmore $\left(f_{s} 51\right)$, Irish Sea $\left(f_{s} 18\right)$, and The Minch $\left(f_{s} 4\right)$ and the documented advance of the Irish Sea Ice Stream to the Isles of Scilly (Scourse and Furze, 2001; Hiemstra et al. 2006) is placed in this stage. We infer further concomitant decline of the North Channel Ice Stream initiated in the preceding stage. We thus expand on the details of the competition between these two central ice streams and the evolution of the North Channel saddle as was inferred in Stage IV of Greenwood and Clark (2009b). From this stage onwards marginal positions are based on the retreat-pattern reconstruction of Clark et al. (2012). Based on the available chronological information (Section 3.3) we start retreat of ice from the shelf edge and in the northern North Sea (Clark et al. 2012).

\subsubsection{Stage 7 (time-transgressive)}

East-west ice flow over northern Scotland ( $f_{s} 3$ and $\left.f_{s} 62\right)$ requires a resumption of an ice divide located over the northwest Highlands. This ice divide is dominant over Grampian-sourced ice although a western secondary divide can be accommodated and is re-established in full in the following stage. An independent but connected ice cap on Shetland orientated northeast-southwest is also inferred back from subsequent stages. The ice sheet margins are stepped back following the retreat pattern reconstruction (Clark et al. 2012). Topographically constrained fast-flowing ice flows west to east over northern England $\left(f_{s} 10\right)$. At the coast ice flow is deflected southwards either due to a remnant ice mass over the southern North Sea, or as part of a major ice tongue from northern England, 'North Sea Lobe'(see Clark et al. 2012). Fs69, fs99, fs 18 and $f s 84$ show the changing effect of ice flow patterns emanating into the eastern Irish Sea as the ice stream retreats, and the thinning effect on the ice sheet in northern England $\left(f s 20, f_{s} 10\right)$. The Irish Sea deglaciates rapidly (e.g. Chiverrell et al. 2013 and references therein), but likely punctuated by multiple oscillations of the ice margin, as dictated by the retreat pattern reconstruction (Clark et al. 2012). As parts of the ice sheet uncouple smaller ice masses expand once buttressing is removed. Fs 42 , fs 21 and $f$ s 16 describe initial retreat and decoupling from the Welsh ice cap. Stage 7 corresponds with Irish Stage Va (Greenwood and Clark, 2009b).

\subsubsection{Stage 8 (time-transgressive)}

Retreat in northern England progresses by thinning $\left(f_{s} 48\right)$ then retreat to local high ground, as dictated by the retreat pattern, with accordant local changes in flow patterns $\left(f_{s} 70, f_{s} 71, f_{s} 41, f_{s} 80\right.$, $\left.f_{s} 65, f_{s} 66, f_{s} 43\right)$, the details of which are not shown on Fig. 8. The Lake District-Yorkshire Dales centred ice mass separates from a now predominantly Scottish-centred ice sheet. Short lived local oscillations of the ice sheet margins likely occur during separation of each ice mass. Progressive thinning of the Scottish ice mass occurs $\left(f_{s} 5, f s 56, f s 45\right)$, which remains reasonably extensive to account for ice moving down the northeast coast, necessitated by the retreat pattern, and a connection with Irish ice is maintained $\left(f_{s} 39, f_{s} 40\right)$. The Scottish ice divide shifts west to return to its Highland position possibly due to reactivation and retreat of The Minch Ice Stream $\left(f_{s} 5\right)$. The Welsh ice cap starts to retreat and thin, breaking into two separate domes $\left(f s 76, f_{s} 74, f s 87, f_{s} 91\right)$. Stage 8 corresponds with Irish Stage Vb-c (Greenwood and Clark, 2009b).

\subsubsection{Stage 9 (time-transgressive)}


Ice over northern England and Wales is reduced to small ice caps and glaciers. Separated from the Irish Ice Sheet a saddle forms between separate Highland and Southern Upland centred ice divides $(f s 25, f s 24)$ as the ice sheet thins. We infer separation of a Shetland ice cap by shrinking of offshore margins and symmetry $\left(f_{s} 61\right)$. From the relative chronologies of the retreat pattern and flowsets ice had retreated inland from the northeast Scottish coast and an ice lobe emanating from the Moray Firth $\left(f_{s} \sigma\right)$ flows onshore $\left(f_{s} 100\right)$. A thin ice sheet is documented by network of small ice-stream flowsets ( $f s 45, f s 56, f s 64, f s 26, f s 64$ ) deflected by topography in central and eastern Scotland. An ice dome is inferred centred on the Cheviots (Clapperton et al. 1970) to account for deflection of ice flow patterns around the area $(f s 14, f s 12$ and $f s 37)$ and satisfy the retreat pattern. This stage corresponds to Irish stage VI-VII (Greenwood and Clark, 2009b).

\subsubsection{Stage 10 (time-transgressive)}

Final retreat to Highland Scotland progresses by topographically constrained ice flow $\left(f_{s} 46, f_{s} 79\right.$, $\left.f_{s} 44, f s 55, f_{s} 53, f_{s} 47, f_{s} 82\right)$. Minor expansion of Highland ice occurs following uncoupling from Southern Upland ice mass to account for flow patterns $f_{s} 23$ and $f_{s} 28$.

During the final time-transgressive stages (Stages 7-10) the snapshot nature of the reconstruction misses any oscillations and readvances that occurred as the ice sheet separated into constituent parts, which are not individually shown in the maps (e.g. ice-free enclaves identified in northern England occurring before final retreat of ice from the Irish Sea and Lake District (Livingstone et al. 2010bc, 2012)). Only five flowsets could not be explained within these 10 stages and may be inherited from a previous glaciation $\left(f_{s} 96, f s 97, f_{s} 92, f_{s} 35\right.$ and $\left.f_{s} 93\right)$. Of these, all except $f s 35$, are based on fewer than 10 lineations and could not be classified (Table S1).

\subsection{Timing of events}

Our 10-stage reconstruction of the ice-sheet configuration respects the sequence of events described by the relative-age relationships of the constituent flowsets (Table 2). At present there is no satisfactory way to directly date palaeo-ice flow-lines and therefore we must consider the available dates that 'bracket' advance and retreat of the ice sheet to add an absolute chronology (e.g. Kleman et al. 2006). There are relatively few dates that constrain the timing of build-up of the ice sheet, and no clear pattern emerges from the spatial distribution of the dates that do exist (Chiverrell and Thomas, 2010; Hughes et al. 2011). This reflects multiple nucleation sites and the asynchronous nature of the maximum limits in different sectors of the ice sheet (Clark et al. 2012) as well as preservation issues for older dates. The youngest dates constraining ice build-up cluster $\sim 30 \mathrm{ka} \mathrm{BP}$ (Lawson, 1984; Sutherland, 1984; Sutherland et al. , 1984; Hedges et al. , 1994; Fitzpatrick, 1965; Jardine et al. 1988; von Weynmarn and Edwards, 1973; Sutherland and Walker, 1984). Marine core evidence from the Barra Fan suggests that the ice sheet had marine margins by 29 ka BP (Scourse et al. 2009), and had expanded to the shelf edge in multiple locations by $\sim 27 \mathrm{ka} \mathrm{BP}$ (Wilson et al. 2002; Everest et al. 2013). Together with our reconstruction of ice-flow pattern build-up (Stages 13 ) this evidence suggests that the younger ages (as above) seem improbable and require revisiting (see also Bradwell et al. 2008a). Although we correlate Stages 2 and 3 with Irish Stages I and II of Greenwood and Clark (2009b), we suggest a slightly later timing based on the Scottish chronology; Stages 1-3 occurring between 32-28 ka. We place Stages 4 and 5 as occurring $28-26 \mathrm{ka}$. Confluent ice cover over the North Sea must have occurred prior to $25 \mathrm{ka} \mathrm{BP}$ but after $33 \mathrm{ka} \mathrm{BP}$ (Sejrup et al. 1994), and European rivers discharged onto the Celtic continental margin via the English Channel 
483 (Fleuve Manche) between 30-18 ka (Toucanne et al. 2010). The Irish Sea Ice Stream maximum 484 advance to the Isles of Scilly was likely a short lived event occurring 24-23 ka BP (Ó Cofaigh and 485 Evans, 2007; McCarroll et al. 2010; Chiverrell et al. 2013) and so Stage 6 is placed at 24 ka.

486 Stages 7-10 are placed as occurring 22-15 ka following on from the reconstructed retreat pattern 487 (Clark et al. 2012); additional dates included in the updated database can be accommodated within 488 error bounds. Ice had retreated from the majority of northern England by $17 \mathrm{ka}$ (Stage 9) (Pinson et 489 al. 2013). High-elevation summits became exposed due to ice-sheet thinning at $\sim 20-17 \mathrm{ka}$ in Wales 490 (Glasser et al. 2012) and 16-15 ka in NW Scotland (Fabel et al. 2012).

\section{Discussion}

Our model is consistent with many of the long-established ice-divide locations; Highland Scotland, Southern Uplands, Grampians, Cheviots, Outer Hebrides, Shetland, Lake District, Pennines and Wales (Evans et al. 2005 and references therein). During maximum extent the last BIS operated as an integrated ice sheet, first with a primary N-S ice divide running along the western mountainous regions from North Scotland to the southern Lake District (Fig 8; Stages 4-5), and then switching to a shelf-edge parallel configuration with a primary divide running NE-SW across the North Channel following confluence with the Scandinavian Ice Sheet (Fig 8; Stages 5-6). The flow pattern configuration during confluence of British and Scandinavian ice is remarkably similar to that produced by Geikie (1894). Flow pattern changes after $\sim 22$ ka document development of a polycentric ice-sheet structure before disintegration to multiple locations, the youngest flow patterns recording changes and oscillations as local ice centres re-establish and uncouple (Stages 7-10). Initial growth of ice from Scotland (Stages 1-2), movement of the ice-sheet centre south (Stages 36 ) and eventual emergence of an ice sheet characterised by multiple divide locations and far travelled lobes (Stages 7-10) also compares favourably with recent numerical models of the icesheet flow pattern evolution (Boulton and Hagdorn, 2006; Hubbard et al. 2009).

Our untangling of the sequence of events shows that the landform record provides glimpses of build-up of the ice sheet. Ice expands out of Highland Scotland into Ireland uninhibited by Irish ice, suggesting that the Irish Ice Sheet was not substantial enough at this stage to deflect Scottish ice (Greenwood and Clark, 2009b). In contrast, deflection of ice around Wales and local ice caps over Lewis, the western Southern Uplands and Lake District (Fig 8; Stages 2-4) implies that these ice masses existed prior to advance of Highland-sourced ice. Whereas local ice caps over the Southern Uplands and Lake District were subsumed into the main ice divide (Fig 8; Stage 4), the Welsh ice cap remained an independent feature throughout (Fig 8). This is in agreement with the conclusion of Jansson and Glasser (2008) but contrasts with the results of numerical modelling that show ice expansion from a single Scottish ice mass invading both Ireland and Wales (Boulton and Hagdorn, 2006).

Some ice divides are persistent features recurring in successive flow geometries whilst others are transient, and some experience substantial migrations $(6-100 \mathrm{~km})$. The most persistent feature is the N-S 'Highland Scotland' ice divide, which shifts in absolute position (and extension south), pivoting from N-S through NW-SE, NE-SW and returning to a N-S orientation, but remains a characteristic feature of all time-slices (Fig 8). The near-constancy of this divide is reflected in the 
dominant direction of glacial-erratic transport to the east or west either side of the approximate location of this N-S trending divide (based on published erratic data compiled in Clark et al. 2004; Fig. 4b). The Welsh ice divide is also a particularly stable feature moving $<10 \mathrm{~km}$ to the east and west, and once established the divide/saddle connection to the Irish Ice Sheet persists across the North Channel (despite shifts of up to $40 \mathrm{~km}$ in absolute position) until the latest deglacial stages. In northern England and southern Scotland ice-flow-pattern geometry is highly dynamic, (see also Salt and Evans, 2005; Mitchell, 1994, 2007; Evans et al. 2009; Livingstone et al. 2008, 2010abc; Finlayson et al. 2010, 2014) reflecting the change from the simpler maximum extent flow configuration to one of multiple competing ice domes as deglaciation progresses. This result explains the complex landform record and flowset overprinting found in this central sector of the country (Fig 3; Hughes et al. 2010) and demonstrates that the landform record chronicles several different ice-sheet configurations. Predominantly west-east ice-flow patterns initially record ice flow breaching the Pennines from an ice divide centred on, or west of, the Cumbrian Mountains. From this position the ice divide pivots eastward $\sim 50 \mathrm{~km}$ to run WSW to ESE from the Cumbrian Mountains to the Howgill Fells, demonstrating that an ice dome centred on the Lake District only occurred during deglacial and early build-up stages.

A major revelation evident from the flowset map (Fig. 3) is the close relationship of ice-flow patterns with topography in Britain. The majority of flowsets exhibit at least some accord with topographic variations (Fig. 7b). Our examination of relationships between flowset types, sizes, relative ages and geometries with the underlying topography and the retreat pattern lead us to propose that topography had the greatest influence on flow patterns during deglaciation; thick ice (relative to topography) was maintained until the maximum extent was reached (Stages 5-6) after which ice-surface lowering preceded longitudinal retreat. Our logic is that flowsets that ignore topographic variations were produced when the direction of ice-surface slope was dominant in controlling ice-flow direction. Flowsets constrained by topography were generated when variations in the subglacial relief were the dominant control. Under thick ice, the location and migration of divides alone controls the evolution of flow-pattern configuration but as the ice thins the topography of the bed increasingly influences flow-pattern geometry, eventually dominating over orientation changes resulting from divide migration (Kleman and Hättestrand, 1999; Kleman et al., 1999). The last BIS is interpreted to have undergone such a transition, and we hypothesise that the change in configuration occurred due to the presence or absence of marine-terminating margins (Fig. 9). At maximum extent the ice extends to the edge of the continental shelf creating extensive marineterminating margins (Stages 4-5). When accumulation exceeds ice loss (by melting and calving) the ice sheet grows yielding a thick ice sheet where divide location and flow geometry are largely independent of topography (i.e. an ice sheet sensu stricto) (Stages 5-6). When ice loss exceeds accumulation, the ice sheet thins and the flow geometry is increasingly influenced by basal topography; ice divides becoming anchored to major upland areas (creating a complex of ice caps) (Stages 7-9).

In support of this conceptual interpretation the retreat pattern also records a signature of ice-sheet thinning (Clark et al. 2012). For example, lateral meltwater channels document lobes of ice retreating around the topographic obstacle of the Forest of Bowland towards the Howgill Fells (Hughes, 2009; Clark et al. 2012). This is consistent with the reconstructed flow-pattern evolution 
which records a change from ice flow overriding the topographic bump ( $f_{s} 31$; Stage 6$)$ to being deflected around it ( $f s 69, f s 70, f s 73$; Stage 7$)$. The same sequence of early topographicallyunconstrained ice flow followed by ice flow along major valleys was also proposed for the Welsh ice cap (Jansson and Glasser, 2004, Glasser et al. 2012). The later stages of the BIS appear more analogous to the present day Antarctic Peninsula (Rignot et al. 2011) and later stages of the Scandinavian (Arnold and Sharp, 2002) and Innuitan Ice Sheets (England et al. 2006). The ice sheet therefore had different styles of operation; dynamics of mountain-centred or heavily topographically-governed ice sheets are different to thick ice sheets, especially in the scale and timing of response to climate. For example, ice flow will be funnelled to specific locations and increasingly divided into fast and slow flow regimes over short distances with an increased potential for a complex hydrological system, possibly creating an ice sheet more sensitive to external climatic changes. Retreat rates are also likely to be spatially variable dependent on the specific topographical setting of each section of the ice sheet margin (Jamieson et al. 2012).

The pattern of deflection followed by retreat around (rather than over or towards) topographic obstacles is repeated around the country at various scales (Stages 7-10). For example, ice is deflected by and retreats around the Cheviots (Fig. 5), Moray Firth and Strathmore ice lobes retreat around the Eastern Grampians, the Irish Sea Ice Stream is deflected by and retreats around the Welsh ice cap and Scottish ice is deflected by and retreats around the Outer Hebrides ice cap. An ice sheet structure of local domes and far-travelled lobes (Stages 7-10) is similar to those proposed for the Innuitian Ice Sheet (England et al., 2006) and the deglacial stages of the Scandinavian Ice Sheet over Denmark (Kjær et al., 2003), and raises the question of whether some of the peripheral ice domes were cold-based creating a networked basal thermal regime (e.g. Kleman and Glasser, 2007, Kleman and Hättestrand, 1999). Field evidence and modelling results show that the Welsh ice cap was cold-based for much of the last glaciation, including low elevation sites, and particularly when coupled to the Irish Sea ice lobe (Patton et al. 2013; Jansson and Glasser, 2004, 2008; Sahlin et al. 2009). Mitchell $(2008,2007)$ describes evidence for cold-based ice on the Cheviots and the northern Pennines, and the landscape of the Cairngorms has for a long time been ascribed to the distribution of cold ice at the ice sheet bed (Sugden, 1968; Hall and Glasser, 2003). This conception of retreat also explains the limited extension of Lake District and Cheviot sourced erratics and the lack of foreign lithologies within these regions (Clark et al. 2004; Figs. 4b, 5). The presence of cold-based ice close to the periphery of the ice sheet has implications for the position of the southernmost limit in England. For example, cold-based ice could explain the apparent absence of glacial deposits and landforms on the Cleveland Hills and Peak District and therefore support a more southerly ice limit incorporating these areas. Terrestrial cosmogenic isotope dating from the Island of Lundy has indicated that this location may have hosted a cold-based non-erosive ice cap during the last glaciation (Rolfe et al. 2012).

Numerical and isostatic models of the last BIS have produced disparate values for the altitude of the ice surface, largely reflecting uncertainties in the boundary conditions used, such as the nature of the ice-sheet bed and the spatial extent. Values range from between 1800-1000 m and 1200-500 m in central Scotland and North Wales respectively (Boulton et al. 1977, 1985, 1991), with more recent models generating maximum elevations closer to the higher end of these ranges; 2250-1500 m (Boulton and Hagdorn, 2006) and $1200 \mathrm{~m}$ in Wales (Patton et al. 2013). Isostatic models 
generate maximum values between 2500-1000 m (Lambeck, 1991, 1995; Johnston and Lambeck, 2000; Shennan et al., 2002). Our results for an initial 'thick' ice sheet satisfies the demand of the isostatic record and provides additional evidence to reject the interpretation of the mapped trimlines as representing the highest elevation reached by the BIS during the last glacial (Kuchar et al. 2012). That the oldest flowsets demand a persistent major N-S ice divide, defining the highest point on the ice-sheet surface to sit within $100 \mathrm{~km}$ of previously proposed nunatak locations implies that the ice sheet must have risen above these peaks during these stages. Presuming that surface profiles derived from modern ice masses are a good analogue for past ice sheets, we use the formulae of $\mathrm{Ng}$ et al. (2010) to calculate the minimum possible divide height based on the distance from the ice-sheet margin to the reconstructed divide position. This approach reconstructs the divide over northern Scotland during Stages 5-6 reaching at least $1400 \mathrm{~m}$ elevation, $400 \mathrm{~m}$ higher than the highest suggested trimline in northern Scotland (McCarroll et al. 1995; Ballantyne and Hallam, 2001). Over northern England we calculate the minimum divide height to be $1000 \mathrm{~m}, \sim 100 \mathrm{~m}$ higher than the highest proposed palaeonunatak in the Lake District (Lamb and Ballantyne, 1998). The observed trimlines instead reflect either an englacial thermal boundary defining the extent of cold-based ice on upland summits as concluded by Ballantyne (2010) and Fabel et al. (2012) or may be inherited from a previous glaciation or represent the ice-sheet surface achieved following thinning prior to marginal retreat (Stages 7-10). If the latter, the presence of trimlines may indicate that that ice sheet had a low surface profile relative to relief for a significant proportion of the glacial cycle.

Our conception of a bi-modal ice-sheet geometry related to ice-surface elevation implies that the ice loading distribution varied during the glaciation. At an early stage the centre of mass moves south, but then settles over southwest Scotland and the North Channel until separation of the British and Irish Ice Sheets. In our reconstruction, assuming ice divides coincide with greatest ice thickness, western Scotland (together with Ireland) was the site of both most sustained ice loading during the last glaciation slightly west of the locations predicted by existing isostatic modelling: northern Irish Sea (Lambeck, 1995) and Midland Valley of Scotland (Shennan et al., 2006). Scotland sustains 'thicker' ice for longest, and the south-eastern parts are only briefly coherently integrated with the rest of the ice sheet (Fig. 8). The dominance of the western side of the ice sheet is reflected in the combined observations from the retreat pattern, flow patterns and dates; confluence of British and Irish ice in the North Channel persisted until after deglaciation of the Irish Sea and southern part of the ice sheet. The overall SW-NE orientation of the ice sheet parallel with the continental shelf edge indicates that proximity to the North Atlantic precipitation source was essential to the persistence of the BIS, and that the ice sheet itself created a rain shadow effect in the southeast, enhancing the dominant west-east precipitation gradient over the British Isles (Chandler and Gregory, 1976). It is therefore likely that the advance and retreat of the last British-Irish Ice Sheet was highly sensitive to changes in precipitation patterns and the movement of the Polar Front (Scourse et al. 2009; Happienemi et al. 2010), as also appears to have been the case during earlier glaciations (Lee et al. 2012; Thierens et al. 2012).

Changes in flow-pattern geometry may both reflect and/or be a driver of changes in ice-sheet mass balance. Increased mass loss from the ice sheet may have been driven by external factors, such as sea level rise, changing precipitation patterns and/or temperatures, or internal ice dynamics. We 
transitions in the ice-sheet flow-pattern geometry (Fig. 9). Increasing IRD flux delivery west to the Barra Fan at $29-28 \mathrm{ka}$ (Scourse et al. 2009) is consistent with ice reaching the shelf edge and the development of the North Channel Ice Stream (Stage 4; 28-27 ka). Coupling and uncoupling with Scandinavian-sourced ice in the North Sea led to pivoting of the primary BIS ice divide and abrupt changes in orientation of ice flow over north Scotland and the North Sea (Fig 8; Stage 5). We propose that the second major change in geometry, from a thick (relative to topography) integrated ice sheet reaching the shelf edge with a simple ice-divide structure (Stage 5, 27-26 ka) to a thin ice sheet (relative to topography) comprising multiple ice centres (Stage 7, 22 ka), was driven by icesurface lowering initiated by increased ice stream discharge (Pritchard et al. 2009). Break up of ice in the North Sea by progressive opening up of an embayment (Bradwell et al. 2008a; Clark et al. 2012) facilitated ice streaming along the north-eastern sector of the ice sheet into the North Sea, which was coeval with advancement of the Irish Sea Ice Stream and continued ice streaming in the Minch and North Channel (Stage 6, 24 ka). This led to increased calving and melt from the ice sheet in multiple locations, lowering the surface profile to create a new ice sheet form. The flowpattern record thus illustrates one cycle of dynamic reorganisation (or binge-purge behaviour) as predicted by numerical modelling (Hubbard et al. 2009). Greatest ice-mass loss from the BritishIrish Ice Sheet, quantified by using IRD volume as a proxy for iceberg discharge, occurred between 27-25 ka and 17-16 ka BP, with peak IRD flux occurring at $24 \mathrm{ka}$ BP (Haapanieni et al. 2009; Hibbert et al. 2010), coeval with the switch from a thick to thin ice-sheet geometry. This supports our conceptualisation (Fig. 9) of bi-modal states for an ice sheet with and without significant marine-terminating margins.

\section{Conclusions}

We have organised the complex and fragmentary terrestrial subglacial bedform record in Britain into 10 snapshots of ice-flow configuration via a process of glaciological inversion (Fig. 8). The process of systematic mapping followed by careful analysis of the pattern and distribution of landforms facilitated untangling of individual flow events (Fig. 3, Table S1) and their relative order (Table 2) and also generated new templates for flowset identification (Table 1). We are able to explain $95 \%$ of the identified flowsets in a 10-stage model of ice-sheet flow-configuration evolution. This would suggest that the observed subglacial bedform record (Hughes et al. 2010) is almost entirely a product of the last glacial cycle. However we acknowledge that our chronology is tentative and some older flowsets could be inherited from a previous glaciation.

Only a few flowsets are identifiable in the preserved record that constrain the build-up of the ice sheet Fig 8; Stages 1-3) but the oldest flowsets are large and topographically unconstrained and record an ice mass of reasonable size and thickness centred over Highland Scotland. As ice expands, more southerly ice masses, with the exception of the Welsh ice cap, are incorporated into the main ice-sheet structure. During maximum glacial extent the centre of the ice sheet shifts south and the ice sheet operates as an integrated ice mass with a primary N-S trending divide. Ice streaming results in substantial shifts in the flow-pattern structure and the ice sheet assumes a shelfparallel orientation (Stages 4-6), which is maintained throughout retreat (Stages 7-10). Initial thinning, interpreted as driven by ice stream activity, creates an ice sheet composed of multiple 
domes and lobes with a complex basal-thermal structure, before final retreat to multiple locations on the western side of the country. The main findings we draw from the reconstruction are:

1. Most flow patterns are indicative of 'thin ice' relative to basal topography and yield a multidomed ice sheet. The complexity of the flowsets in the central sector of the ice sheet reflects the changing relative dominance and interaction of different ice domes, and confirms the British subglacial landform record as a palimpsest archive of multiple ice-sheet geometries.

2. Some ice divides were persistent features but the majority were either transitory or experienced substantial migrations in position $(6-100 \mathrm{~km})$.

3. The largest, most spatially extensive flowsets are satisfied by a large simple divide structure which suggests that at its peak the last BIS must have been thick, the surface certainly clearing the highest mountains. This finding strengthens the interpretation that high altitude erosion limits in Scotland represent englacial thermal transitions, rather than the maximum surface height of the last glacial ice sheet. Many of the formerly proposed nunatak sites lie close to or directly below the reconstructed principle ice divide during the early stages of our model.

4. By teasing out discrete flowsets and their relative timing, we find that the last BIS had two main modes of flow-pattern geometry (Fig. 9). A thick (relative to topography) integrated ice sheet reaching the shelf edge with a simple ice-divide structure and a thin ice sheet (relative to topography) comprising multiple ice centres and with a more complex flow structure. Such changes in the distribution of ice mass during the last glacial have implications for reconstructions of the isostatic loading history in Western Europe.

5. For large ice sheets such as the Laurentide and Fennoscandian, cross-cutting flow patterns mostly appear to record migrations of ice divides, switching of ice streams (e.g. Boulton and Clark, 1990; Clark et al. 2000), or patchy sticky-spot preservation (Trommelen et al. 2012). In contrast, the complexity of flow patterns identified for the BIS (Fig. 3) almost precluded a reconstruction using these ideas as templates (Section 2.3.3), until it was appreciated that for a smaller (and thinner) ice sheet, basal topography plays a much larger role in determining ice flow and much of the cross-cutting is actually a record of ice-thickness changes. Recognition of these associations stimulated new templates for flow-pattern reconstruction (Table 1; TT thinning) and a bi-modal configuration model for the last BIS (Fig. 9).

6. We infer that ice streams and break up of ice in the North Sea were key drivers of changes in icesheet geometry and thickness.

We consider our 10-stage model to be the simplest interpretation of the information contained within the geomorphological record of former ice-sheet flow patterns, and that it will serve as a framework for more detailed studies. Reducing the uncertainty in the timing of changes in ice-sheet geometry is critical to understanding the factors controlling the observed dynamic changes in ice flow. This requires a sustained attempt to improve the ice-sheet margin chronology both for icesheet retreat and build-up and integration of the geomorphological record with stratigraphic observations at the ice-sheet scale (e.g. Livingstone et al. 2012; Finlayson et al. 2014). Further advances will also be achieved by increasing the spatial coverage of offshore geomorphological mapping (e.g. Dunlop et al. 2010; Howe et al. 2012). We have proposed simple explanations for the changes in configuration of the ice sheet through time. An alternative, and more robust approach to examine dynamic causes behind the observed changes in ice-flow geometry, would be to use the 
building blocks or ingredients of our reconstruction (flowsets, retreat pattern and relative chronology) as a test or input to improve and constrain numerical ice-sheet models (e.g. Li et al. 2007; Napieralski et al. 2007ab; Hubbard et al. 2009; Patton et al. 2013; Stokes et al. 2012) and we provide a larger version of Fig. 3 and full documentation describing each flowset as supplementary material (Fig. S1, Table S1). Such approaches in combination with glacial isostatic adjustment modelling (e.g. Bradley et al. 2011) would also test our hypotheses regarding the controls on changes in ice-sheet thickness, proposed locations of ice streams and cold-based ice and to investigate the timing and duration of the observed ice-sheet flow-pattern configurations.

\section{Acknowledgements}

Mapping, flowset identification and initial reconstruction work formed part of the $\mathrm{PhD}$ thesis of ALCH, conducted at the University of Sheffield (2004-2008) funded by a British Geological Survey-NERC PhD Studentship (NER/S/A/2004/12102). Some additional work and writing was conducted while ALCH was funded by the Leverhulme Trust (GLIMPSE Project) at Swansea University (October 2008-December 2011) and in her present position at the University of Bergen (January 2012-). We thank Sarah Greenwood and Jonathan Lee for their insightful comments and Bethan Davies and Michelle Trommelen for their thorough reviews which improved the quality of the manuscript. CJJ publishes with permission of the Executive Director of the British Geological Survey.

\section{Supplementary Material}

Large version of the flowset map (Fig. S1).

Table describing each flowset (Table S1).

\section{References}

Arnold, N., Sharp, M. 2002. Flow variability in the Scandinavian ice sheet: modelling the coupling between ice sheet flow and hydrology. Quat. Sci. Rev. 21, 485-502.

Ballantyne, C.K. 2010. Extent and deglacial chronology of the last British-Irish Ice Sheet: implications of exposure dating using cosmogenic isotopes. J. Quat. Sci. 25, 515-534.

Ballantyne, C.K., Hallam, G.E. 2001. Maximum altitude of Late Devensian glaciation on South Uist, Outer Hebrides, Scotland. Proc. Geol. Assoc.112, 155-167.

Benn, D.I., Evans, D.J.A. 2010. Glaciers and Glaciation (2nd ed.). Hodder Education, London.

Boston, C.M., Evans, D.J., Cofaigh, C.Ó. 2010. Styles of till deposition at the margin of the Last Glacial Maximum North Sea lobe of the British-Irish Ice Sheet: an assessment based on geochemical properties of glacigenic deposits in eastern England. Quat. Sci. Rev. 29, 3184-3211.

Boulton, G.S., Clark, C.D. 1990. A highly mobile Laurentide Ice Sheet revealed by satellite images of glacial lineations. Nature, 346, 813-817.

Boulton, G.S., Hagdorn, M.K. 2006. Glaciology of the British Isles Ice Sheet during the last glacial cycle: form, flow, streams and lobes. Quat. Sci. Rev. 25, 3359-3390.

Boulton, G.S., Jones, A.S., Clayton, K.M., Kenning, M.J. 1977. A British ice sheet model and patterns of glacial erosion and deposition in Britain and Ireland, In: Shotton, F. (Ed.), British Quaternary Studies: Recent advances. Clarendon Press, Oxford. 
Boulton, G.S.. Peacock, J.D., Sutherland, D.G. 1991. Quaternary. In Craig, G.Y. (ed.) The Geology of Scotland. Geol. Soc. Spec. Pub., London, 503-544.

Bradley, S.L., Milne, G.A., Shennan, I., Edwards, R. 2011. An improved glacial isostatic adjustment model for the British Isles. J. Quat. Sci., 26, 541-552.

Bradwell, T., Stoker, M., Larter, R. 2007. Geomorphological signature and flow dynamics of the Minch palaeo-ice stream, northwest Scotland. J. Quat. Sci. 22, 609-617.

Bradwell, T., Stoker, M., Golledge, N., Wilson, C., Merritt, J., Long, D., Everest, J., Hestvik, O., Stevenson, A., Hubbard, A., Finlayson, A., Mathers, H. 2008a. The northern sector of the last British Ice Sheet: maximum extent and demise. Earth Sci. Rev.88, 207-226.

Bradwell, T., Stoker, M.S., Krabbendam, K. 2008b. Megagrooves and streamlined bedrock in NW Scotland: the role of ice streams in landscape evolution. Geomorph. 97, 135-156.

Chandler, T.J., Gregory, S. 1976. The climate of the British Isles. Longman, London.

Charlesworth, J.K. 1957. The Quaternary Era. Arnold, London.

Chiverrell, R.C., Thomas, G.S.P. 2010. Extent and timing of the Last Glacial Maximum (LGM) in Britain and Ireland: A review. J. Quat. Sci. 25, 535-549.

Chiverrell, R.C., Thrasher, I.M., Thomas, G.S.P., Lang, A., Scourse, J.D., van Landeghem, K.J.J., McCarroll, D., Clark, C.D., Ó Cofaigh, C., Evans, D.J.A., Ballantyne, C.K. 2013. Bayesian modelling the retreat of the Irish Sea Ice Stream. J. Quat. Sci. 28, 200-209.

Clapperton, C.M. 1970. The evidence for a Cheviot ice cap. Trans. Inst. Br. Geogr.29, 31-45.

Clark, C.D. 1997. Reconstructing the evolutionary dynamics of former ice sheets using multi-temporal evidence, remote sensing and GIS. Quat. Sci. Rev.16, 1067-1092.

Clark, C.D. 1999. Glaciodynamic context of subglacial bedform generation and preservation. Ann. Glaciol. 28, 23-32.

Clark, C.D., Meehan, R.T. 2001. Subglacial bedform geomorphology of the Irish Ice Sheet reveals major configuration changes during growth and decay. J. Quat. Sci. 16, 483-496.

Clark, C.D., Knight, J.K., Gray, J.T. 2000. Geomorphological reconstruction of the Labrador Sector of the Laurentide Ice Sheet. Quat. Sci. Rev. 19, 1343-1366.

Clark, C.D., Evans, D.J., Khatwa, A., Bradwell, T., Jordan, C.J., Marsh, S.H., Mitchell, W.A., Bateman, M.D. 2004. Map and GIS database of glacial landforms and features related to the last British Ice Sheet. Boreas 33, 359-375.

Clark, C.D., Hughes, A.L.C., Greenwood, S.L., Jordan, C.J., Sejrup, H-P. 2012. Pattern and timing of retreat of the last British-Irish Ice Sheet. Quaternary Science Reviews, 44, 112-146.

Davies, B. J., Roberts, D. H., Bridgland, D. R., Ó Cofaigh, C. 2012. Dynamic Devensian ice flow in NE England: a sedimentological reconstruction. Boreas, 41, 337-366.

De Angelis, H., Kleman, J. 2005. Palaeo-ice streams in the northern Keewatin sector of the Laurentide ice sheet. Ann. Glaciol. 42, 135-144.

De Angelis, H., Kleman, J. 2007. Palaeo-ice streams in the Foxe/Baffin sector of the Laurentide Ice Sheet. Quat. Sci. Rev. 26, 1313-1331.

Dunlop, P, Clark, C.D., Hindmarsh, R.C.A. 2008. Bed Ribbing Instability Explanation: Testing a numerical model of ribbed moraine formation arising from coupled flow of ice and subglacial sediment. J. Geophys. Res. - Earth Surface, 113 (F03005), 1-15.

Dunlop, P., Shannon, R., McCabe, M., Quinn, R. and Doyle, E. 2010. Marine geophysical evidence for ice sheet extension and recession on the Malin Shelf: New evidence for the western limits of the British Irish Ice Sheet . Marine Geol. 276, 86-99.

England, J.H., Atkinson, N., Bednarski, J., Duyke, A.S., Hodgson, D.A., Ó Cofaigh, C. 2006. The Innuitian Ice Sheet: configuration, dynamics and chronology. Quat. Sci. Rev. 25, 7-8.

Evans, D.J.A., Clark, C.D., Mitchell, W.A. 2005. The last British Ice Sheet: A review of the evidence utilised in the compilation of the Glacial Map of Britain. Earth Sci. Rev. 70, 253-312. 
Evans, D.J.A., Ó Cofaigh, C. 2003. Depositional evidence for marginal oscillations of the Irish Sea ice stream in southeast Ireland during the last glaciation. Boreas 32, 76-101.

Evans, D.J.A, Livingstone, S.J., Vieli, A., Ó Cofaigh, C. 2009. The palaeoglaciology of the central sector of the British and Irish Ice Sheet: reconciling glacial geomorphology and preliminary ice sheet modelling. Quat. Sci. Rev. 28, 739-757.

Everest, J., Bradwell, T., Golledge, N. 2005. Subglacial Landforms of the Tweed Palaeo-Ice Stream. Scott. Geogr. J. 121, 163-174.

Fabel, D., Ballantyne, C., Xu, S. 2012. Trimlines, blockfields, mountain-top erratics and the vertical dimensions of the last British-Irish Ice Sheet in NW Scotland. Quat. Sci. Rev. 55, 91-102.

Finlayson, A., Merritt, J., Browne, M., Merritt, J.E., McMillan, A., Whitbread, K. 2010. Ice sheet advance, dynamics, and decay configurations: evidence from west central Scotland. Quat. Sci. Rev. 29, 969-988.

Fitzpatrick, E.A. 1965. An interglacial soil at Teindland, Morayshire. Nat. 207, 621-622.

Geikie, J. 1894. The Great Ice Age and its relation to the antiquity of man. Edward Stanford, London.

Glasser, N.F., Hughes, P.D., Fenton, C., Schnabel, C. Rother, H. 2012. 10Be and 26Al exposure-age dating of bedrock surfaces on the Aran Ridge, Wales: Evidence for a thick Welsh Ice Cap at the LGM. J. Quat. Sci. 27, 97-104.

Golledge, N.R., Stoker, M. 2006. A palaeo-ice stream of the British Ice Sheet in eastern Scotland. Boreas 35, 231-243.

Graham, A.G.C., Lonergan, L., Stoker, M.S. 2007. Evidence for Late Pleistocene ice stream activity in the Witch Ground Basin, central North Sea, from seismic reflection data. Quat. Sci. Rev. 26, 627-643.

Graham AGC, Lonergan L, Stoker MS. 2010. Depositional environments and chronology of Late Weichselian glaciation and deglaciation in the central North Sea, Boreas, 39, pp. 471-491.

Greenwood, S.L., Clark, C.D. 2009a. Reconstructing the last Irish Ice Sheet 1: changing flow geometries and ice flow dynamics deciphered from the glacial landform record. Quat. Sci. Rev. 28, 3085-3100.

Greenwood, S.L., Clark, C.D. 2009b. Reconstructing the last Irish Ice Sheet 2: a geomorphologically-driven model of ice sheet growth, retreat and dynamics. Quat. Sci. Rev. 28, 3101-3123.

Hall, A.M., Glasser, N.F. 2003. Reconstructing the basal thermal regime of an ice stream in a landscape of selective linear erosion: Glen Avon, Cairngorm Mountains, Scotland. Boreas 32, 191-207.

Haapaniemi, A.I., Scourse, J.D., Peck, V.L., Kennedy, H., Kennedy, P., Hemming, S.R., Furze, M.F. A., Pieńkowski, A.J., Austin, W.E. N., Walden, J., Wadsworth, E. Hall, I.R. 2010. Source, timing, frequency and flux of ice-rafted detritus to the Northeast Atlantic margin, 30-12 ka: testing the Heinrich precursor hypothesis. Boreas, 39, 576-591.

Hedges, R.E.M., Housley, R.A., Ramsey, C.B., Van Klinken, G.J. 1994. Radiocarbon-Dates from the Oxford AMS System - Archaeometry Datelist- 18. Archaeom. 36, 337-374.

Hibbert, F.D., Austin, W.E.N., Leng, M.J., Gatliff, R.W. 2010. British Ice Sheet dynamics inferred from North Atlantic ice-rafted debris records spanning the last 175000 years. J. Quat. Sci., 25, 461-482.

Hiemstra, J.F., Evans, D.J.A., Scourse, J.D., McCarroll, D., Furze, M.F.A., Rhodes, E. 2006. New evidence for a grounded Irish Sea glaciation of the Isles of Scilly, UK. Quat. Sci. Rev. 25, 299-309.

Howe, J., Dove, D., Bradwell, T., Gafeira, J. 2012. Submarine geomorphology and glacial history of the Sea of the Hebrides, Scotland. Mar. Geol. 315-318: 64-76.

Hubbard, A., Bradwell, T., Golledge, N., Hall, A., Patton, H., Sugden, D., Cooper, R., Stoker, M. 2009. Dynamic cycles, ice streams and their impact on the extent, chronology and deglaciation of the BritishIrish ice sheet. Quat. Sci. Rev. 28, 758-776.

Hughes, A.L.C. 2009. The last British Ice Sheet: a reconstruction based on glacial landforms. Unpublished $\mathrm{PhD}$ thesis, University of Sheffield.

Hughes, A.L.C., Clark, C.D., Jordan, C.J. 2010. Subglacial bedforms of the last British Ice Sheet. J. Maps, v2010, 543-563. 
Hughes, A.L.C., Greenwood, S.L., Clark, C.D. 2011. Dating constraints on the last British-Irish Ice Sheet: a map and database, J. Maps, v2011, 156-183.

Jamieson, S.S.R., Vieli, A., Livingstone, S.J., Ó Cofaigh, C., Stokes, C.R., Hillenbrand, C-D., Dowdeswell, J.A. 2012. Ice-stream stability on a reverse bed slope. Nature Geoscience 5, 799-802.

Jansson, K.N., Glasser, N.F. 2004. Palaeoglaciology of the Welsh sector of the British-Irish Ice Sheet. J. Geol. Soc. Lond. 161, 1-13.

Jansson, K.N., Glasser, N.F. 2008. Modification of peripheral mountain ranges by former ice sheets: The Brecon Beacons, southern UK. Geomorphol. 97, 178-189.

Jardine, W.G., Dickson, J.H., Haughton, P.D.W., Harkness, D.D., Bowen, D.Q., Sykes, G.A. 1988. A Late middle Devensian interstadial site at Sourlie, near Irvine, Strathclyde. Scott. J. Geol. 24, 288-295.

Johnston, P.J., Lambeck, K. 2000. Automatic inference of ice models from postglacial sea level observations: Theory and application to the British Isles. J. Geophys. Res. 105, 13179-13194.

Kjær, K.H., Houmark-Nielsen, M., Richardt, N. 2003. Ice-flow patterns and dispersal of erratics at the southwestern margin of the last Scandinavian Ice Sheet: signature of palaeo-ice streams. Boreas 32, 130148.

Kleman, J., Borgström, I. 1996. Reconstruction of palaeo-ice sheets: the use of geomorphological data. Earth Surf. Process. Landf. 21, 893-909.

Kleman, J., Hättestrand, C. 1999. Frozen-bed Fennoscandian and Laurentide ice sheets during the Last Glacial Maximum. Nat. 402, 63-66.

Kleman, J., Glasser, N.F. 2007: Subglacial Thermal Organization (STO) of Ice Sheets. Quat. Sci. Rev. 26, 585-597.

Kleman, J., Hättestrand, C., Borgström, I., Stroeven, A. 1997. Fennoscandian palaeoglaciology reconstructed using a glacial geological inversion model. J. Glaciol. 43, 283-299.

Kleman, J., Hättestrand, C., Stroeven, A.P., Jansson, K.N., De Angelis, H., Borgström, I. 2006. Reconstruction of paleo-ice sheets-inversion of their glacial geomorphological record, In: Knight, P.G. (Ed.), Glacier science and environmental change. Blackwell Science Ltd, Oxford, pp. 192-198.

Kuchar, J., Milne, G., Hubbard, A., Patton, H., Bradley, S., Shennan, I., Edwards, R. 2012. Evaluation of a numerical model of the British-Irish ice sheet using relative sea-level data: implications for the interpretation of trimline observations. J. Quat. Sci., 27: 597-605.

Lamb, A.L., Ballantyne, C.K. 1998. Paleonunataks and the altitude of the last ice sheet in the south-west Lake District, England. Proc. Geol. Soc. 109, 305-316.

Lambeck, K. 1991. A model for Devensian and Flandrian glacial rebound and sea-level change in Scotland, In: Sabadini, R., Lambeck, K., Boschi, E. (Eds.), Glacial isostasy, sea level and mantle rheology. Kluwer Academic Publishers, Dordrecht.

Lambeck, K. 1995. Late Devensian and Holocene shorelines of the British Isles and North Sea from models of glacio-hydro-isostatic rebound. J. Geol. Soc. Lond. 152, 437-448.

Lawson, T.J. 1984. Reindeer in the Scottish Quaternary. Quat. Newsl. 42, 1-7.

Lee, J.R., Busschers, F.S., Sejrup, H.P. 2012. Pre-Weichselian Quaternary glaciations of the British Isles, The Netherlands, Norway and adjacent marine areas south of $68^{\circ} \mathrm{N}$ : implications for long-term ice sheet development in northern Europe. Quat. Sci. Rev., 44, 213-228.

Letzer, J.M. 1987. Drumlins of the southern Vale of Eden, In: Ehlers, J., Gibbard, P.L., Rose, J. (Eds.), Glacial deposits in Great Britain and Ireland. Balkema, Rotterdam, pp. 323-334.

Li, Y., Napieralski, J., Harbor, J., Hubbard, A. 2007. Identifying patterns of correspondence between modeled flow directions and field evidence: An automated flow direction analysis. Comput. Geosci. 33, 141-150.

Livingstone, S.J., Ó Cofaigh, C., Evans, D.J.A. 2008. The glacial geomorphology of the central sector of the British-Irish Ice Sheet. J. Maps, v2008, 358-377. 
Livingstone, S.J., Ó Cofaigh, C., Evans, D.J.A. 2010a. A major ice drainage pathway of the last British-Irish Ice Sheet: the Tyne Gap, northern England. J. Quat. Sci. 25, 354-370. oscillation and proglacial lake formation in the Solway Lowlands (Cumbria, UK) during Late Devensian deglaciation. Boreas, 39, 505-527.

Livingstone, S.J., Evans, D.J.A., Ó Cofaigh, C. 2010c. Re-advance of Scottish Ice into the Solway Lowlands (Cumbria, UK) during the Main Late Devensian deglaciation. Quat. Sci. Rev. 29, 2544-2570.

Livingstone, S.J., Evans, D.J.A., Ó Cofaigh, C., Davies, B.J., Merritt, J.W., Huddart, D., Mitchell, W.A., Roberts, D.H., Yorke, L. 2012. Glaciodynamics of the central sector of the last British-Irish Ice Sheet in Northern England. Earth Sci. Rev. 111, 25-55.

McCarroll, D., Ballantyne, C.K., Nesje, A., Dahl, S.O. 1995. Nunataks of the last ice sheet in northwest Scotland. Boreas 24, 305-323.

McCarroll, D., Stone, J.O., Ballantyne, C.K., Scourse, J.D., Fifield, L.K., Evans, D.J.A., Hiemstra, J.F. 2010. Exposure-age constraints on the extent, timing and rate of retreat of the last Irish Sea ice stream. Quat. Sci. Rev. 29, 1844-1852.

Merritt, J.W., Auton, C.A., Firth, C.R. 1995. Ice-proximal glaciomarine sedimentation and sea-level change in the Inverness area, Scotland: a review of the deglaciation of a major ice stream of the British late Devensian ice sheet. Quat. Sci. Rev. 14, 289-329.

Mitchell, W.A. 1994. Drumlins in ice-sheet reconstructions, with reference to the western Pennines, northern England. Sediment. Geol. 91, 313-331.

Mitchell, W.A. 2007. Reconstructions of the Late Devensian (Dimlington Stadial) British-Irish Ice Sheet: the role of the upper Tees drumlin field, north Pennines, England. Proc. Yorks. Geol. Soc. 56, 221-234.

Mitchell, W.A. 2008. Quaternary Geology of part of the Kale Water catchment, Western Cheviot Hills, southern Scotland. Scottish J. Geol. 44, 51-63.

Napieralski, J., Harbor, J., Li, Y. 2007a. Glacial geomorphology and geographic information systems. Earth Sci. Rev.85, 1-22.

Napieralski, J., Hubbard, A., Li, Y., Harbor, J., Stroeven, A.P., Kleman, J., Alm, G., Jansson, K.N. 2007b. Towards a GIS assessment of numerical ice-sheet model performance using geomorphological data. J. Glaciol. 53, 71-83.

Ng, F., Barr, I.D., Clark, C.D. 2010. Using the surface profiles of modern ice masses to inform palaeoglacier reconstruction. Quat. Sci. Rev. 29, 3240-3255.

Ó Cofaigh, C., Evans, D.J.A. 2007. Radiocarbon constraints on the age of the maximum advance of the British-Irish Ice Sheet in the Celtic Sea. Quat. Sci. Rev. 26, 1197-1203.

Patton, H., Hubbard, A., Glasser, N.F., Bradwell, T., Golledge, N.R. 2013. The last Welsh Ice Cap: Part 2 Dynamics of a topographically controlled ice cap. Boreas. 42, 491-510.

Peck, V.L., Hall, I.R., Zahn, R., Elderfield, H., Grousset, F., Hemming, S.R., Scourse, J.D. 2006. High resolution evidence for linkages between NW European ice sheet instability and Atlantic Meridional Overturning Circulation. Earth Planet. Sci. Lett. 243, 476-488.

Pinson, L.J.W., Vardy, M.E., Dix, J.K., Henstock, T.J., Bull, J.M., MacLachlan, S.E. 2013. Deglacial history of glacial lake Windermere, UK; implications for the central British and Irish Ice Sheet. J. Quat. Sci., 28, 83-94.

Pritchard, H.D., Arthern R.J., Vaughan, D.G., Edwards, L.A. 2009. Extensive dynamic thinning on the margins of the Greenland and Antarctic ice sheets. Nature, 461, 971-975.

Rignot, E., Mouginot, J. Scheuchl, B. 2011. Ice Flow of the Antarctic Ice Sheet. Science, 333, 1427-1430.

Roberts, D.H., Dackombe, R.V., Thomas, G.S.P. 2007. Palaeo ice streaming in the central sector of the British-Irish Ice Sheet during the Last Glacial Maximum: evidence from the northern Irish Sea Basin. Boreas. 36,115-129. 
Roberts, D.H., Evans, D.J.A., Lodwick, J., Cox, N.J. 2013. The subglacial and ice-marginal signature of the North Sea Lobe of the British-Irish Ice Sheet during the Last Glacial Maximum at Upgang, North Yorkshire, UK. Proc. Geol. Assoc., 124, 503-519.

Rolfe, C.J., Hughes, P.D., Fenton, C.R., Schnabel, C., Xu, S., Brown, A.G. 2012. Paired 10Be and 26Al exposure ages from Lundy: new evidence for the extent and timing of Devensian glaciation in the southern British Isles. Quat. Sci. Rev. 43, pp. 61-73.

Rose, J., Letzer, J.M. 1977. Superimposed drumlins. J. Glaciol. 18, 471-480.

Sahlin, E.A.U., Glasser, N. F., Jansson, K. N., Hambrey, M. J. 2009: Connectivity analyses of valley patterns indicate preservation of a preglacial fluvial valley system in the Dyfi basin, Wales. Proc. Geol. Assoc. $120,245-255$.

Salt, K.E., Evans, D.J.A. 2005. Superimposed subglacially streamlined landforms of southwest Scotland. Scott. Geogr. J. 120, 133-147.

Scourse, J.D., Furze, F.A. 2001. A critical review of the glaciomarine model for Irish Sea deglaciation: evidence from southern Britain, the Celtic shelf and adjacent continental slope. J. Quat. Sci. 16, 419-434.

Scourse, J.D., Haapaniemi, A.I., Colmenero-Hidalgo, E., Peck, V.L., Hall, I.R., Austin, W.E.N., Knutz, P.C., Zahn, R. 2009. Growth, dynamics and deglaciation of the last British-Irish Ice Sheet: the deep-sea icerafted detritus record. Quat. Sci. Rev. 28, 3066-3084.

Sejrup, H.P., Haflidason, H., Aarseth, I., King, E., Forsberg, C.F., Long, D., Rokoengen, K. 1994. Late Weichselian glaciation history of the northern North Sea. Boreas 23, 1-13.

Shennan, I., Bradley, S., Milne, G., Brooks, A., Bassett, S., Hamilton, S. 2006. Relative sea-level changes, glacial isostatic modelling and ice-sheet reconstructions from the British Isles since the Last Glacial Maximum. J. Quat. Sci. 21, 585-599.

Shennan, I., Peltier, W.R., Drummond, R., Horton, B. 2002. Global to local scale parameters determining relative sea level changes and the post glacial isostatic adjustment of Great Britain. Quat. Sci. Rev. 21, 397-408.

Sissons, J.B. 1967. The Evolution of Scotland's Scenery. Oliver and Boyd, Edinburgh.

Smith, M.J., Knight, J. 2011. Palaeoglaciology of the last Irish ice sheet reconstructed from striae evidence. Quat. Sci. Rev., 30, 147-160.

Stoker, M.S., Bradwell, T. 2005. The Minch palaeo-ice stream, NW sector of the British-Irish Ice Sheet. J. Geol. Soc. Lond. 163, 425-428.

Stoker, M S, Bradwell, T, Howe, J A, Wilkinson, I P, McIntyre, K. 2009. Lateglacial ice-cap dynamics in NW Scotland: evidence from the fjords of the Summer Isles region. Quat. Sci. Rev. 28, 3161-3184.

Stokes, C.R., Clark, C.D. 1999. Geomorphological criteria for identifying Pleistocene ice streams. Ann. Glaciol. 28, 67-75.

Stokes, C.R., Tarasov, L., Dyke, A.S. 2012. Dynamics of the North American Ice Sheet Complex during its inception and build-up to the Last Glacial Maximum. Quat. Sci. Rev. 50, 86-104.

Sugden, D.E. 1968. The selectivity of glacial erosion in the Cairngorm Mountains, Scotland. Trans. Inst. Br. Geogr.45, 79-92.

Sutherland, D.G. 1984. The Quaternary deposits and landforms of Scotland and the neighbouring shelves: a review. Quat. Sci. Rev. 3, 157-254.

Sutherland, D.G., Ballantyne, C.K., Walker, M.J.C. 1984. Late Quaternary glaciation and environmental change on St-Kilda, Scotland and their paleoclimatic significance. Boreas 13, 261-272.

Sutherland, D.G., Walker, M.J.C. 1984. A late Devensian ice-free area and possible interglacial site on the Isle of Lewis, Scotland. Nat. 309, 701-703.

Thierens, M., Pirlet, H., Colin, C., Latruwe, K., Vanhaecke, F., Lee, J.R., Stuut, J.-B., Titschack, J., Huvenne, V.A.I., Dorschel, B., Wheeler, A.J., Henriet. J.-P. 2012. Ice-rafting from the British-Irish ice sheet since the earliest Pleistocene (2.6 million years ago): implications for long-term mid-latitudinal icesheet growth in the North Atlantic region. Quat. Sci. Rev. 44, 229-240. 
1029 Toucanne, S., Zaragosi, S., Bourillet, J-F., Marieu, V., Cremer, M., Kageyama, M. Van Vliet-Lanoë, B., 1030 Eynaud, F., Turon, J-L., Gibbard, P.L. 2010. The first estimation of Fleuve Manche palaeoriver discharge 1031 during the last deglaciation: Evidence for Fennoscandian ice sheet meltwater flow in the English Channel 1032 ca 20-18 ka ago, Earth. Planet. Sci. Lett., .290, 459-473.

1033 Trommelen, M., Ross, M., Campbell, J.E. 2012. Glacial terrain zone analysis of a fragmented 1034 paleoglaciologic record, southeast Keewatin sector of the Laurentide Ice Sheet. Quat. Sci. Rev., 40, 1-20. 1035 1036 1037 1038 Von Weymarn, J., Edwards, K. J. 1973. Interstadial site on the Island of Lewis. Nature. 246, 473-474. 1039 Wilson, L.J., Austin, W.E.N., Jansen, E. 2002. The last British Ice Sheet: growth, maximum extent and 1040 deglaciation. Polar Res. 21, 243-250.

1041 Wright, W.B. 1914. The Quaternary Ice Age. The Macmillan Co., New York. 
Tables

1043

1044

1045

1046

1047

1048

Table 1 Flowset classification templates used in this reconstruction developed from Boulton and Clark (1990), Kleman and Borgström (1996), Kleman et al. (1997, 2006), Clark (1999), Stokes and Clark (1999), Greenwood and Clark (2009a). Key characteristics for each type listed as dashed bullet points, additional characteristics with a '+'.

\begin{tabular}{|c|c|c|c|}
\hline Flowset classification & Bedform properties & Landform associations & Glaciodynamic context \\
\hline \multirow[t]{2}{*}{$\begin{array}{l}\text { Isochronous } \\
\text { 'rubber-stamped' imprint }\end{array}$} & $\begin{array}{l}\text { - no cross cutting within flowset } \\
\text { - high lineation parallel conformity } \\
\text { - may ignore local topography } \\
\text { - gradual trends in lineation morphometry } \\
\text { and distribution }\end{array}$ & $\begin{array}{l}\text { - no aligned eskers } \\
\text { - no association with end } \\
\text { moraines }\end{array}$ & $\begin{array}{l}\text { - internal rather than marginal flow patterns } \\
\text { - stable flow directions } \\
\text { - range of ice thicknesses } \\
\text { - warm based } \\
\text { = Ice sheet interior: } \text { sheet flow }\end{array}$ \\
\hline & $\begin{array}{l}\text { + highly attenuated lineations } \\
+ \text { abrupt lateral margins } \\
\text { + highly convergent flow patterns }\end{array}$ & $\begin{array}{l}\text { + lateral shear moraines } \\
+ \text { trough mouth fans }\end{array}$ & $\begin{array}{l}+ \text { order of magnitude faster ice velocity } \\
=\text { Ice sheet interior: } \text { stream flow }\end{array}$ \\
\hline \multirow[t]{4}{*}{$\begin{array}{l}\text { Time-transgressive (TT) } \\
\text { 'smudged' imprint }\end{array}$} & $\begin{array}{l}\text { - lower parallel conformity of lineations } \\
\text { - cross-cutting bedforms within flowset } \\
\text { - abrupt spatial discontinuities in lineation } \\
\text { morphometry and distribution }\end{array}$ & & $\begin{array}{l}\text { - changing flow geometry due to divide migration } \\
\text { - changing flow geometry due to outlet migration } \\
\text { - warm based } \\
\text { = Flow-line migration }\end{array}$ \\
\hline & $\begin{array}{l}+ \text { elements of pattern correspond to local } \\
\text { topography } \\
+ \text { cross-cutting is clustered around } \\
\text { topographic obstacles }\end{array}$ & & $\begin{array}{l}\text { - ice surface altitude decreases/increases relative to local } \\
\text { topography } \\
\text { - warm based } \\
=\text { Thinning/thickening ice }\end{array}$ \\
\hline & $\begin{array}{l}\text { + pattern corresponds to local topography } \\
+ \text { lobate/splaying pattern }\end{array}$ & $\begin{array}{l}+ \text { aligned with eskers } \\
+ \text { associated with end } \\
\text { moraines }\end{array}$ & $\begin{array}{l}\text { - rapidly varying flow directions } \\
\text { - thin ice } \\
\text { - sheet or stream flow } \\
\text { - warm based } \\
\text { = Behind retreating ice sheet margin 'wet-bed' }\end{array}$ \\
\hline & $\begin{array}{l}\text { absence of bedforms: landform record } \\
\text { dominated by meltwater channels }\end{array}$ & $\begin{array}{l}\text { pattern constrained by } \\
\text { local topography }\end{array}$ & $\begin{array}{l}\text { - sheet flow } \\
- \text { frozen bed } \\
\text { - thin ice } \\
=\text { Behind retreating ice margin 'dry-bed' }\end{array}$ \\
\hline
\end{tabular}


Table 2 Flowset relative-age chronology. Horizontal lines separate flowsets that are known to be older or younger than each other, as determined from superimposition of the constituent subglacial bedforms, with the youngest flowsets shown at the top and oldest at the bottom. Many flowsets are laterally adjacent but do not overlap meaning that no relative-age relationship can be defined. Flowsets and/or flowset groups that have no definitive chronological relationship are separated by vertical arrows to demonstrate the uncertainty in their relative timing: e.g. $f s 64$ and $f s 36$ are both older than $f s 72$, but $f s 64$ could be either older, younger or the same age as $f_{s} 36$ and $f_{s} 100$. Dotted horizontal lines mean there is no direct relationship between the two flowsets: e.g. $f s 56$ overprints $r m 12$ and $f s 51$, but $r m 12$ has no relationship with $f s 51$. Flowset numbers are the same as in Fig. 3 and Table S1.

1058

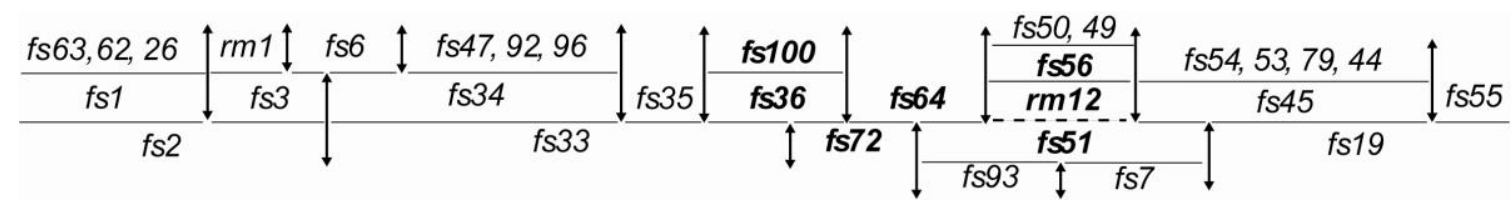

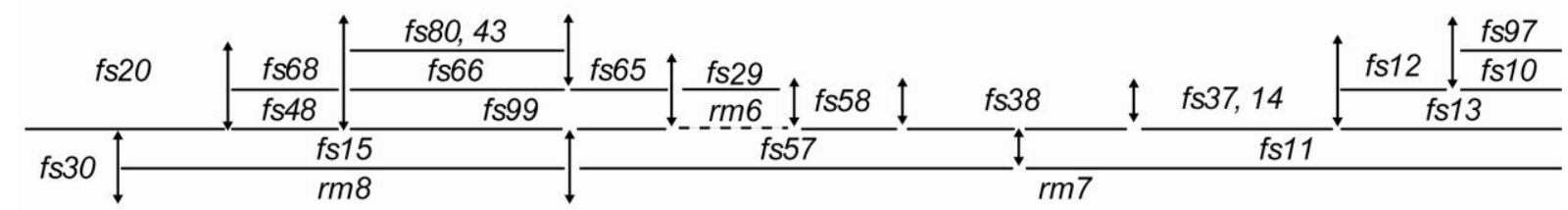

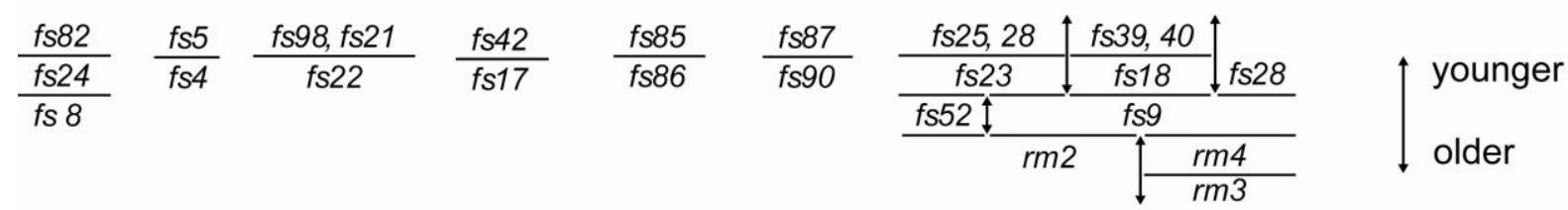


Table 3 Flowset and ancillary evidence groupings underpinning each stage of the reconstruction model (Fig. 8).

\begin{tabular}{|c|c|c|}
\hline & Flowset grouping & curity of interpretation \\
\hline Stage 1 & $\begin{array}{l}\text { ss } 2, f s 33 \\
s s 7 \\
r m 13\end{array}$ & $\begin{array}{l}\text { Irge flowsets, little relationship with topography, stratigraphically oldest in Scotland. } \\
7 \text { is stratigraphically old and so included here, if relative chronology ignored it could be included in Stage } 5 . \\
n 13 \text { is placed here as is aligned with flow direction of } f s 2 \text {. Could be earlier or later; no superimposition information. }\end{array}$ \\
\hline Stage 2 & $\begin{array}{l}f s 2, f s 33 \\
f 52 \\
r m 2, r m 3 \\
r m 7 \\
r m 6\end{array}$ & $\begin{array}{l}\text { Fs } 33 \text { exhibits some smudging, interpreted as due to minor divide migration between Stages 1-2. } \\
\text { Southern Upland and Highland ice connected, Highland ice is deflected around southern ice mass. Fs } 52 \text { is a large but exhibits } \\
\text { signature of thinning/thickening. Placement reverses stratigraphic relationship with } f s 19 \text {, although this relation is equivocal. } \\
R m 3 \text { and } r m 2 \text { document NE-SW ice flow over Rhins of Galloway and Ayrshire. Rm3 precedes } r m 4 . R m 2 \text { probable southwest } \\
\text { extension of } f s 52 \text {; occurs just prior to } f s 52 \text {. } \\
R m 7 \text { must occur before other ice flow signatures in Solway lowlands, uncertain ice flow direction interpreted as broadly W-E. } \\
R m 6 \text { shows SE ice flow from a source over western Southern Uplands, could be earlier. }\end{array}$ \\
\hline Stage 3 & $f s 8, f s 57$ & $\begin{array}{l}\text { Isochronous flowsets, direction supported by streamlined bedrock, erratics and subglacial meltwater (fs57). Fs } 8 \text { identified as part } \\
\text { of inferred North Channel Ice Stream. } \\
\text { Lake District sourced ice expands to south; occurs prior to } f s 31 \text {. }\end{array}$ \\
\hline Stage 4 & $\begin{array}{l}f s 19 \\
f s 15, f s 30, f s \\
f s 22 \\
r m 4\end{array}$ & $\begin{array}{l}\text { Fs } 19 \text { identified as potential ice stream (Forth Ice Stream) based on parallel conformity and convergent pattern. Flow direction } \\
\text { supported by erratics. Exhibits signature of thinning/thickening but must occur after } f s 7 \text { and before } f s 52, f s 55, f s 45 \text {. } \\
\text { Major W-E ice flow over Northern England. All exhibit signs of thinning/thickening. Interpret this as due to proximity to ice } \\
\text { margin. Also W-E ice flow over north-east Wales, no signature of thinning, independent of topography. } \\
R m 4 \text { must occur after } r m 3 \text { and before } f s 9 \text {. }\end{array}$ \\
\hline Stage 5 & $f s 1, f_{s} 34, f_{s} 59$ & $\begin{array}{l}\text { ge and independent of topography indicating thick ice sheet and considerable offshore extent. Fs } 59 \text { interpreted as extension of } \\
\text { Invoke connection with ice over North Sea due to deflection of ice flow over Scotland to NNE. Supported by streamlined } \\
\text { lrock and presence of shelly till on Caithness. Slight smudging in } f s l \text { and } f s 34 \text { indicates slight migration of divides. } \\
13 \text { small flowset but with high parallel conformity, streamlined bedrock and subglacial meltwater traces support flow direction. } \\
7 \text { could be placed here if ignore relative chronology. This would make Stage } 1 \text { unnecessary. } \\
9 \text { cannot be placed with } f s 8 \text { or } f s 19 . F s 9 \text { large flowset difficult to fit into any configuration, possible that more than one ice flow } \\
\text { nt with very similar flow directions represented, indicated by the variety of bedform size populations. Streamlined bedrock and } \\
\text { atics support flow direction. } \\
\text { gh parallel conformity and independent of topography. } \\
\text { flow to SE over Yorkshire Dales. }\end{array}$ \\
\hline Stage 6 & $\left\{\begin{array}{l}f 4 \\
f s 31 \\
f s 51 \\
f s 90, f s 78 \\
f s 18, f s 84 \\
f s 86\end{array}\right.$ & $\begin{array}{l}\text { le feature that can be incorporated into several configurations. } \\
\text { ge flowset supported by streamlined bedrock, some expression of thinning but independent of topography during this stage. } \\
\text { ge flowset, independent of topography, some minor smudging interpreted as due to divide migration. Potential ice stream } \\
\text { rathmore I), but lacks abrupt margins and convergent flow patterns. } \\
\text { sed on only a few drumlins, but consistent flow directions for this stage. } \\
\text { flow converges into northern Irish Sea; some smudging suggests minor fluctuations of flow patterns. Streamlined bedrock } \\
\text { ports flow directions. Could also be grouped with } f s 17 \text { (Stage } 5 \text { ) and } f s 99 \text { (Stage 7). Fs } 84 \text { southward extension of } f s 18 \\
\text { all isochronous flowset, must occur before } f s 85 \text {. }\end{array}$ \\
\hline & $f s 16, f s 77$ & \\
\hline \begin{tabular}{|l} 
Stage 7 \\
TT stage
\end{tabular} & $\begin{array}{l}f s 3 \\
f s 72 \\
f s 42 \\
f s 21, f s 76, f s 60 \\
f s 10, f s 99, f s 69, f s 18 \\
f s 20 \\
f s 62, f s 75, f s 87, f s 91 \\
r m 11, r m 1\end{array}$ & $\begin{array}{l}\text { Ice flow converges to the coast and exhibits some evidence of thinning/thickening, streamlined bedrock and erratic paths are } \\
\text { aligned and suggest extension of flow pattern to south. Must occur after } f s 2 \text {. } \\
\text { Minor orientation changes interpreted as due to changes in the ice divide position. Bedrock supports ice flow direction. } \\
\text { Lobate pattern suggests close to retreating margin. } \\
\text { Topographically constrained ice flow, streamlined bedrock supports ice flow direction. } \\
\text { Isochronous flowsets interpreted as ice streams/ice stream tributaries. Topographically constrained but high parallel conformity. } \\
\text { Subglacial meltwater aligned. } f \text { s } 10 \text { necessitates branching of Southern Uplands ice divide. } \\
\text { Necessitates divide over Pennines. Concordant with moraines and eskers, interpret as close to retreating ice margin. } \\
\text { Small flowsets. Tentatively placed in this stage. } \\
\text { W-E ice flow in Central Scotland }(\mathrm{rm} / 1) \text {. Rml documents topographically constrained ice flow broadly W-E, aligned with } f s 3 \text { and } \\
\text { confined to valley settings. }\end{array}$ \\
\hline & 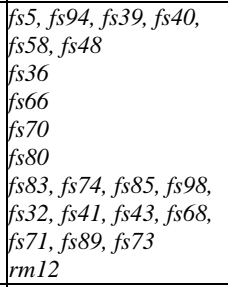 & $\begin{array}{l}\text { Topographically constrained spatially restricted flowsets with smudging due to thinning. } \\
\text { High parallel conformity, could fit into stage } 4 \text { or } 6 \text {, but must be younger than } f s 33 \text { and } f s 72 \text {. Older than } f s 100 \text {. } \\
\text { Aligned esker and smudging so interpreted as deglacial flowset. Younger than } f s 99 \text {. } \\
\text { High parallel conformity, but topographically constrained. Must occur after } f s 69 \text {. } \\
\text { High parallel conformity, younger than } f s 66 \text {, possibly represents readvance. } \\
\text { Topographically constrained and/or deglacial flowsets that follow the above flowsets in northern England and document } \\
\text { topographically constrained retreat back to local upland ice centres. Fs } 32, f s 41, f s 43, f s 68, f s 71, f s 89, f s 80 \text { and } f s 73 \text { occur at end of } \\
\text { this time-transgressive stage but before Stage } 9 \text {. } \\
\text { Must occur before } f s 56 \text {. }\end{array}$ \\
\hline Stage 9 & $\begin{array}{l}f s 6, f_{s} 100 \\
f s 12, f_{s} 56, f s 61, f_{s} 45 \\
f s 64 \\
f s 14 \\
\\
f s 24 \\
f s 25, f s 29 \\
f s 65 \\
f s 63, f s 95, f s 88 \\
f s 37, f_{s} 38 \\
\end{array}$ & $\begin{array}{l}\text { Convergent ice flow into Moray Firth, interpreted as an ice stream. High elongation ratios and parallel conformity. } \\
\text { Topographically constrained ice flow and thinning. Fs } 56 \text { is interpreted as possible ice stream (Strathmore II) and could occur in } \\
\text { Stage } 8 . \\
\text { High parallel conformity, isochronous flowset, surge type fan (Kleman and Borgström, 1996). Occurs after } f s 11 \text { and close to ice } \\
\text { sheet margin. } \\
\text { Erratics and meltwater traces support flow directions. } \\
\text { Deglacial flowsets with evidence of thinning. } \\
\text { Retreat from Solway Firth. } \\
\text { Small flowsets placed here as fit with overall ice flow patterns. } \\
\text { Retreat to south and around Cheviots. Occur between Stage } 9 \text { and Stage } 10 .\end{array}$ \\
\hline \begin{tabular}{|l|} 
Stage 10 \\
TT stage
\end{tabular} & $\begin{array}{l}s 23 \\
f s 27 \\
f 82, f s 81, f s 6 \\
s s 46, f s 47, f s 4 \\
f s 53, f s 54, f s 5 \\
f s 28\end{array}$ & $\begin{array}{l}\text { ographically constrained, flows offshore. Must occur prior to } f_{s} 28 \text { and cannot occur contemporaneously with } f_{s} 25 \text {. } \\
\text { lacial flowset with lobate pattern, based on streamlined bedrock. } \\
\text { all, topographically constrained or deglacial flowsets. Fs } 67 \text { and } f s 81 \text { cannot have occurred at the same time although both part } \\
\text { he deglacial signature. } \\
\text { y high parallel conformity, topographically constrained, clearly superimposes } f s 23 \text { and } f s 9 \text {. Possible readvance of Highland ice } \\
\text { ing uncoupling. } \\
\text { ate pattern within Loch Lomond limit and so probably relates to this stage. }\end{array}$ \\
\hline
\end{tabular}




\section{Figure captions}

Figure 1 (a) Generalised flow patterns (arrows) of the last British-Irish Ice Sheet at its maximum extent (dashed line) as synthesised by Wright (1914) (redrawn from Boulton et al. 1977). (b) Map of British Isles. Key locations mentioned in the text are marked: $\mathrm{A}=\mathrm{Ayrshire}, \mathrm{C}=\mathrm{Caithness}, \mathrm{Cg}=\mathrm{Cairngorm}$, $\mathrm{Ch}=$ Cheviots, $\mathrm{CH}=$ Cleveland Hills, $\mathrm{CM}=$ Cumbrian Mountains, $\mathrm{FC}=$ Firth of Clyde, FoB=Forest of Bowland, FoF = Firth of Forth, Gr=Grampians, HF =Howgill Fells, LD=Lake District, L=Lewis, $\mathrm{M}=$ The Minch, $\mathrm{MF}=$ Moray Firth, $\mathrm{MV}=$ Midland Valley, $\mathrm{NC}=$ North Channel, $\mathrm{OH}=\mathrm{Outer}$ Hebrides, $\mathrm{P}=$ Pennines, $\mathrm{Pb}=$ Pembrokeshire, $\mathrm{PD}=$ Peak District, $\mathrm{YD}=$ Yorkshire Dales. Locations of Figs. 5 and 6 are also shown. Area of the Irish Ice Sheet as considered by Greenwood and Clark (2008ab) shown in grey. In this and subsequent figures, background elevation shading based on NEXTMap Britain (Intermap Technologies, obtained under licence from British Geological Survey (CNERC) and Shuttle Radar Topographic Mission data. Bathymetric contours generated from GEBCO One Minute Grid (GEBCO Digital Atlas published by the British Oceanography Data Centre on behalf of IOC and IHO, 2003).

Figure 2 Illustration of lineation flowset derivation from landform mapping: a) extract from Glacial Map of Britain (Hughes et al. 2010); b) summarised flow patterns from the subglacial-bedform record; c) grouping of flow patterns based on landform proximity, orientation and parallel conformity; d) resulting flowsets.

Figure 3 Flowsets of the last British Ice Sheet. Colours indicate classification class (see key). Inset map shows summary ribbed moraine flow patterns (colours here are arbitrary), derived by drawing flow lines perpendicular to ridges and outlines around the spatial extent. Larger (ISO A2 size) version of the map is available as online supplementary material (Fig. S1).

Figure 4 Ancillary evidence used in reconstruction of ice-sheet flow-pattern geometries: a) Retreat pattern map (black) (Clark et al. 2012). Outline of the Loch Lomond (Younger Dryas) Stadial ice cap (white) (taken from Clark et al. 2004); b) Inferred erratic transport paths (modified from BRITICE database (Clark et al. 2004) (Hughes, 2009)); c) British-Irish dates database (Hughes et al. 2011; v.2).

Figure 5 Example regional reconstruction for northeast England-Scottish border region. Four flow-pattern geometries are derived from the evidence (left panel: flowsets $=$ black, erratic-transport paths $=$ white, retreat pattern = grey): (1) large-scale west-east ice flow places the ice divide to the west, (2) subsequent broadly north-south ice flow along the present-day coastline necessitates an ice divide to the north, (3) topographically-constrained ice flow develops in the Tweed Basin suggesting a thinner ice sheet and ice divides placed over high ground and finally (4) during retreat topographically constrained lobes encircle the high ground of the Cheviots placing an ice divide over or north of the Tweed Basin. We infer cold based ice over the Cheviots, which is supported by the limited spatial expression of Cheviot granite erratics.

Figure 6 Example regional reconstruction for north Scotland. Top panel shows flowsets (black), erratictransport paths (white), shelly-till locations (spotted) and retreat pattern (grey). Below is a sequence of 6 reconstructed ice-sheet geometries that observe the relative-age chronology: (1) NNE ice flow over most of northern Scotland placing an ice divide along Highlands and Grampians. Spatial extent of flowsets suggests relatively extensive ice sheet with an offshore margin (three possible margin positions are shown); (2) Major NNW ice flow over North Scotland and Orkney. Highland ice divide has been pushed south; (3) Switch to W-E ice flow over NE Scotland and Orkney indicating reestablishment of Highland ice divide; (4) Ice divide moves east but configuration remains broadly the same; (5) and (6) retreat towards Highlands and Grampians. 
Figure 7 Components of the synthesis process to aid grouping of regional reconstructions. Grouping flowsets by size and relationship to topography i.e. unconstrained (a) or constrained (b) suggests that the topographically constrained flowsets relate to later stages in the ice-sheet evolution (topographically constrained flowsets are typically the youngest in each region, and vice versa; topographically

Figure 8 Model of flow-pattern evolution of the last British Ice Sheet based on palaeoglaciological inversion of the glacial-landform record. Evolution in ice-sheet geometry is presented as a time-series of snapshots that capture significant changes in flow patterns. Ice sheet extent after and including Stage 5 is derived from the reconstructed retreat pattern (Clark et al. 2012). Divide/saddle locations and flow patterns are depicted as thick and thin lines respectively. Flowset groupings which form the basis for each snapshot are shown in the background. Colour refers to flowset classification as in Fig. 3. Note that some of the stages are regarded as time-transgressive. White circles mark final retreat locations whose size is below the resolution of the maps. Dotted lines in Stage 7 show estimated extent of remnant ice mass in the southern North Sea and grey lines in Stage 8 show flow pattern necessary to account for ice presence along the eastern English coastline at c. $17 \mathrm{ka} \mathrm{BP}$ (see Clark et al. 2012). ScIS = Scandinavian Ice Sheet.

Figure 9 Conceptual schematic of bi-modal configurations for an ice sheet resting on an island landmass: a) hypothetical cross profiles of the two modal ice-surface states; b) plan view of the basal topography (contours as indicated) and flow geometries during each state. Note that $~ 75 \%$ of the bed experiences cross-cutting flow patterns and therefore has the potential to preserve superimposed bedforms. At maximum extent the ice extends to the edge of the continental shelf creating extensive marineterminating margins. When snow accumulation exceeds ice loss by surface melting and iceberg calving (positive mass balance) the ice surface grows yielding a thick ice sheet where divide location and flow geometry are largely independent of topography (i.e. an ice sheet sensu stricto) (1). With a negative mass balance, the ice sheet thins and the flow geometry is increasingly influenced by basal topography; ice divides eventually becoming anchored to major upland areas (creating a complex of ice caps) (2). 

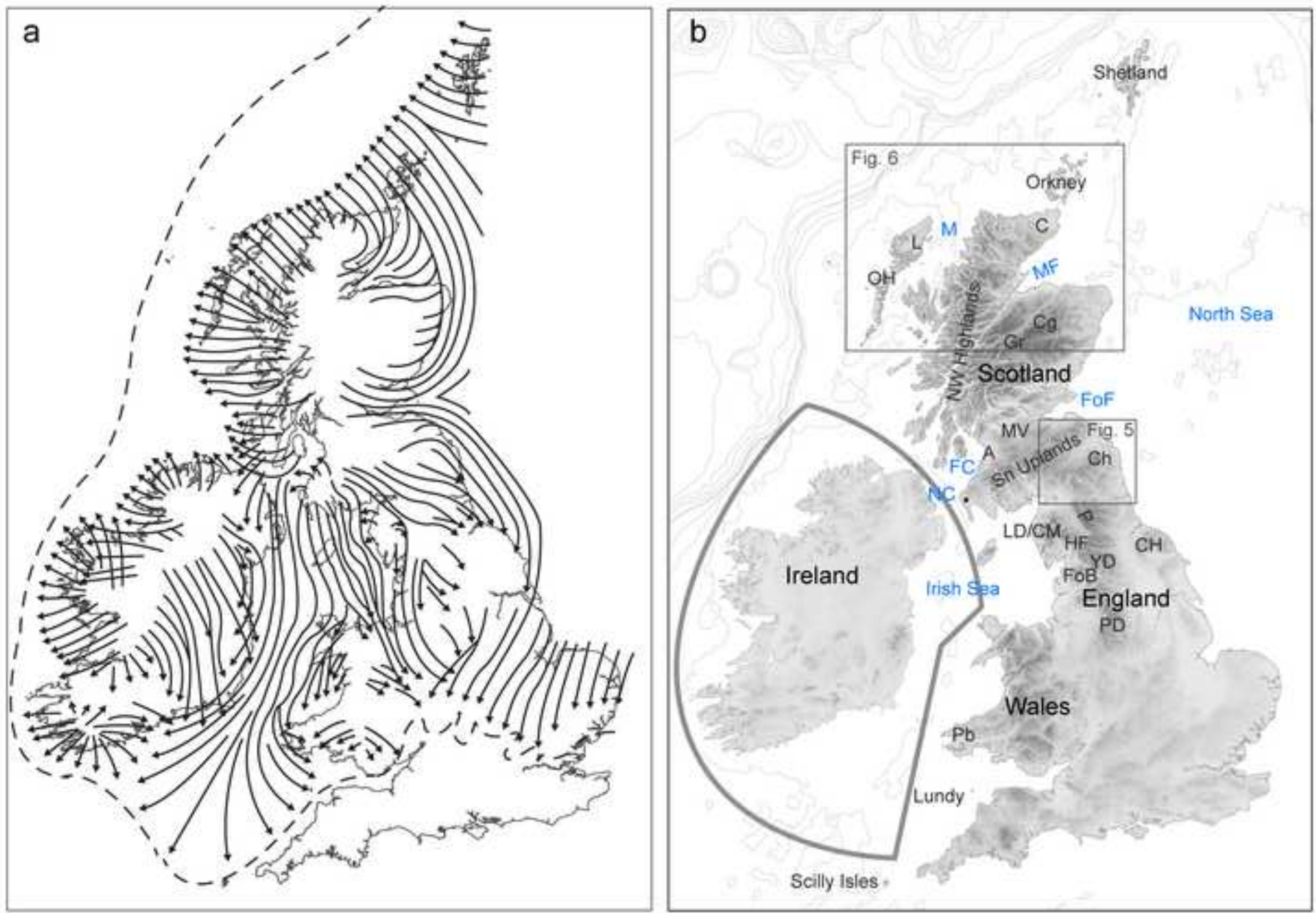
Click here to download high resolution image
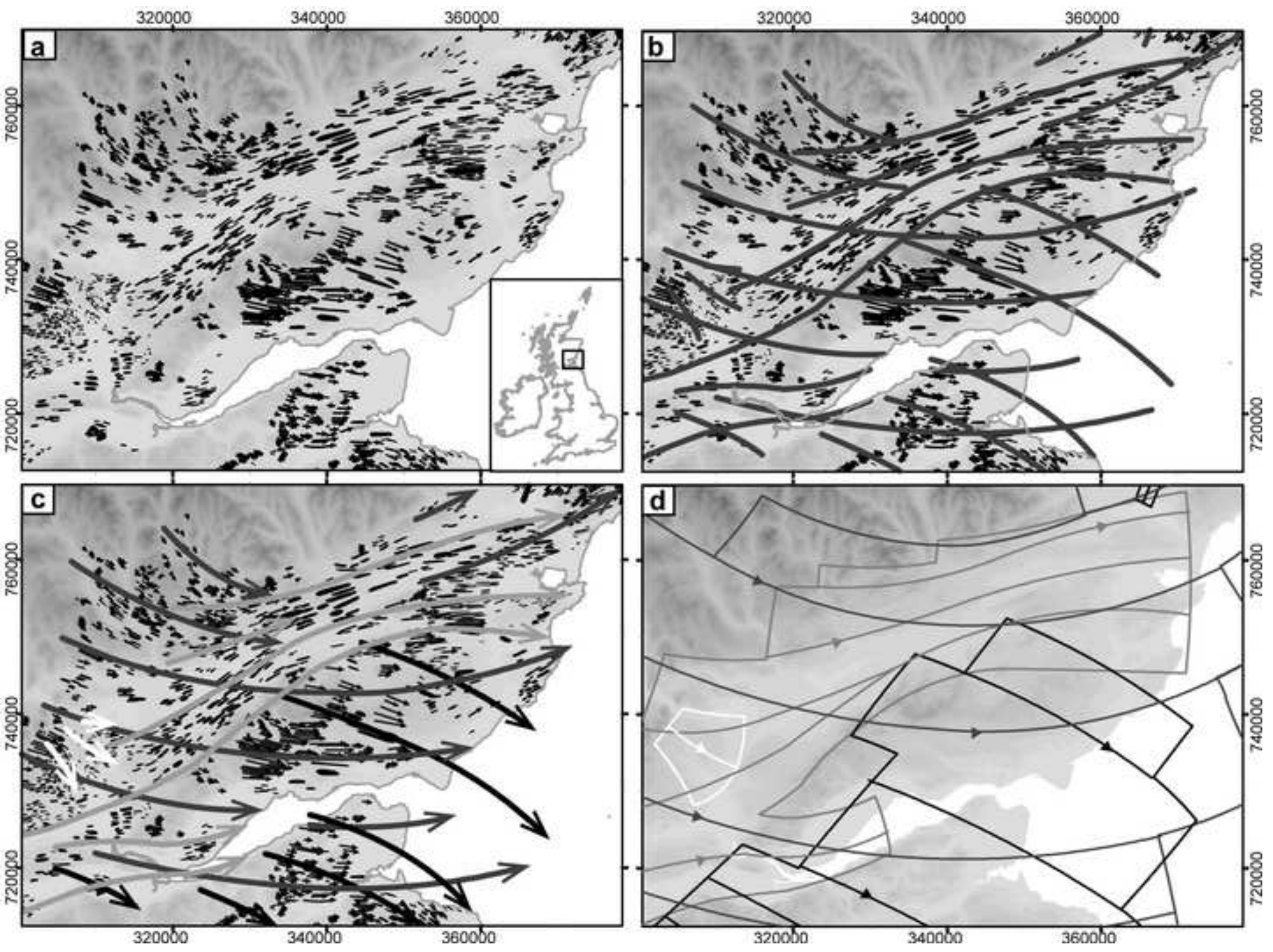


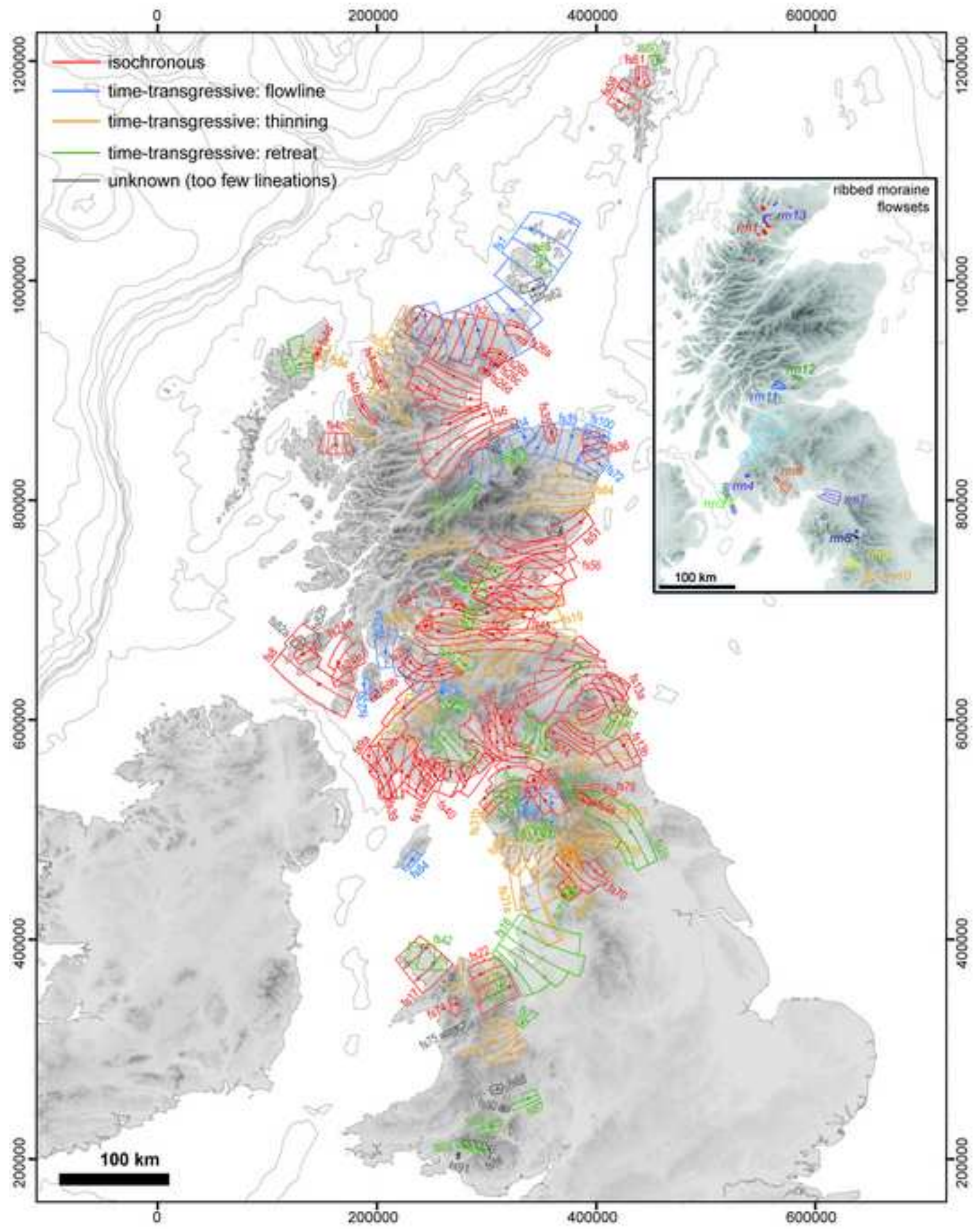$$
\text { . }
$$ 
Click here to download high resolution image

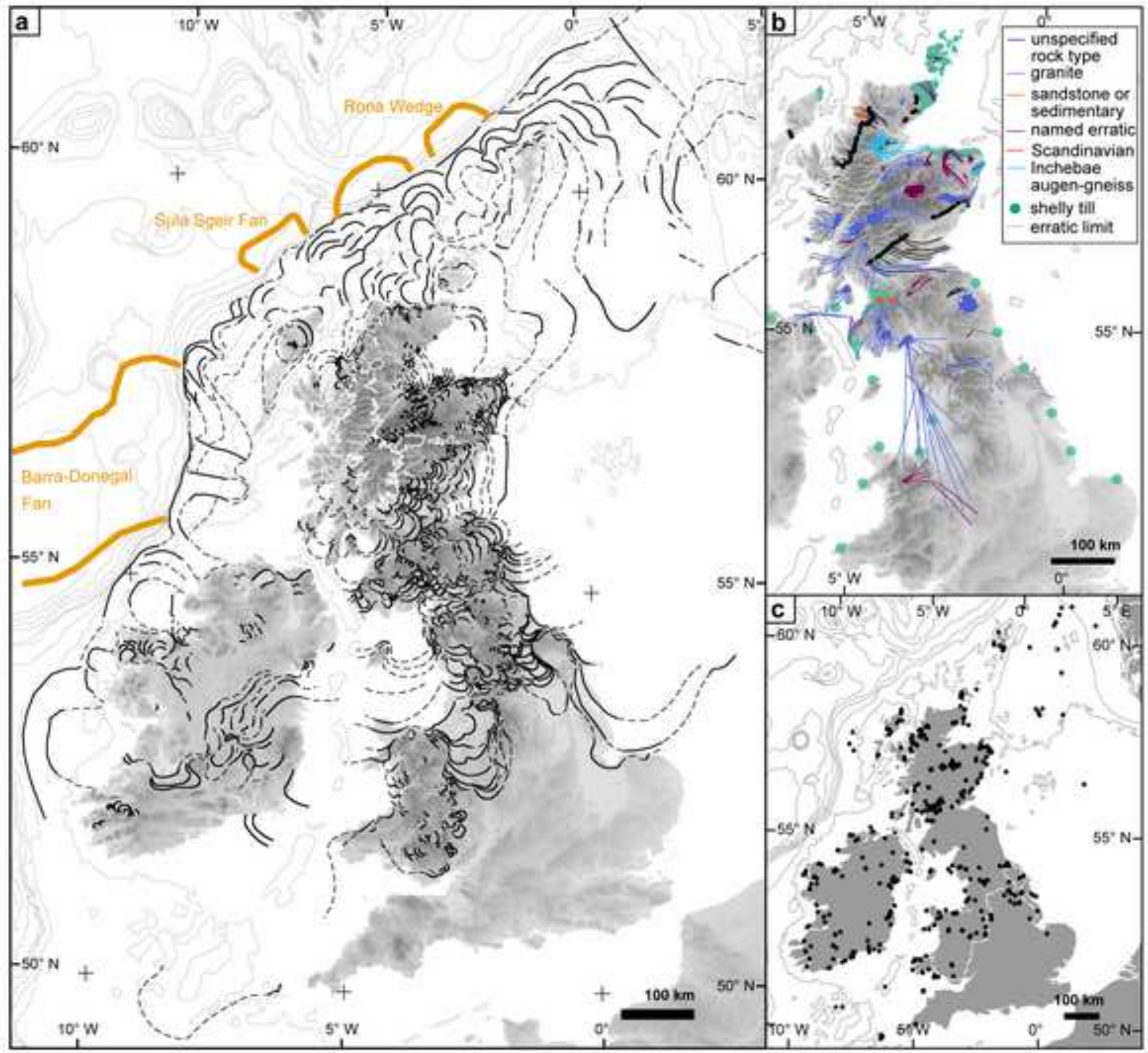



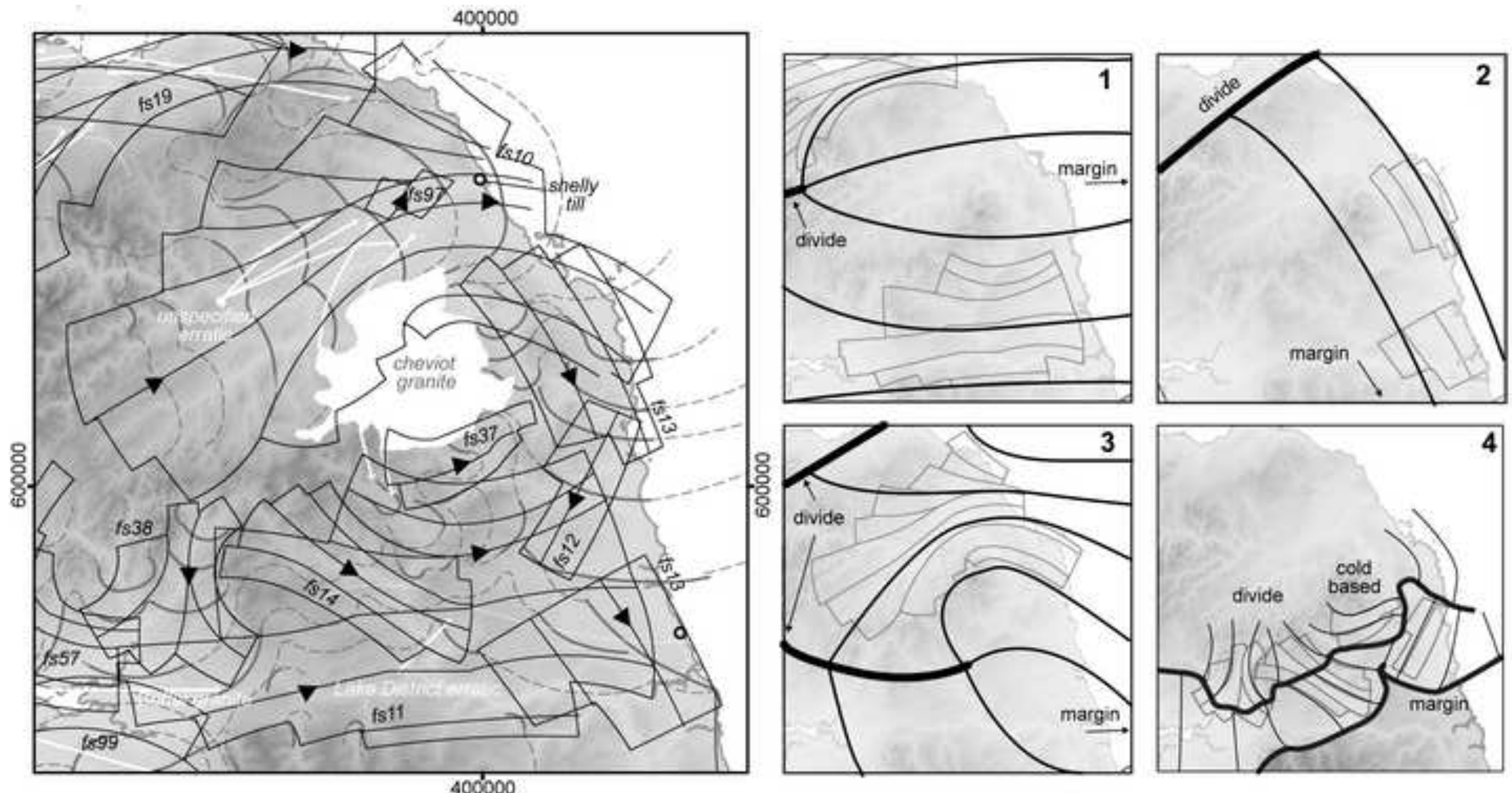
Figure 6

Click here to download high resolution image
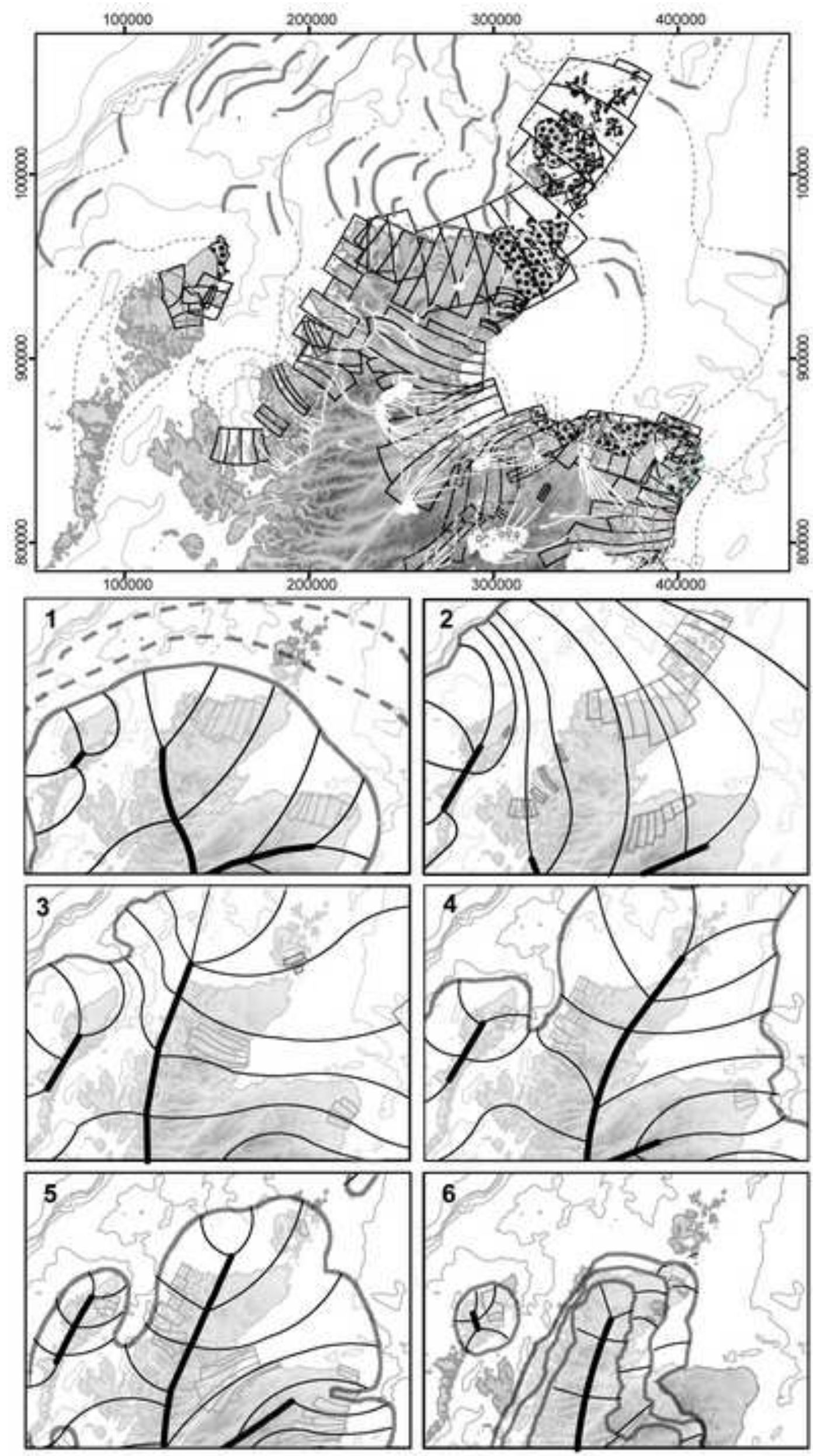


\section{Figure 7}

Click here to download high resolution image
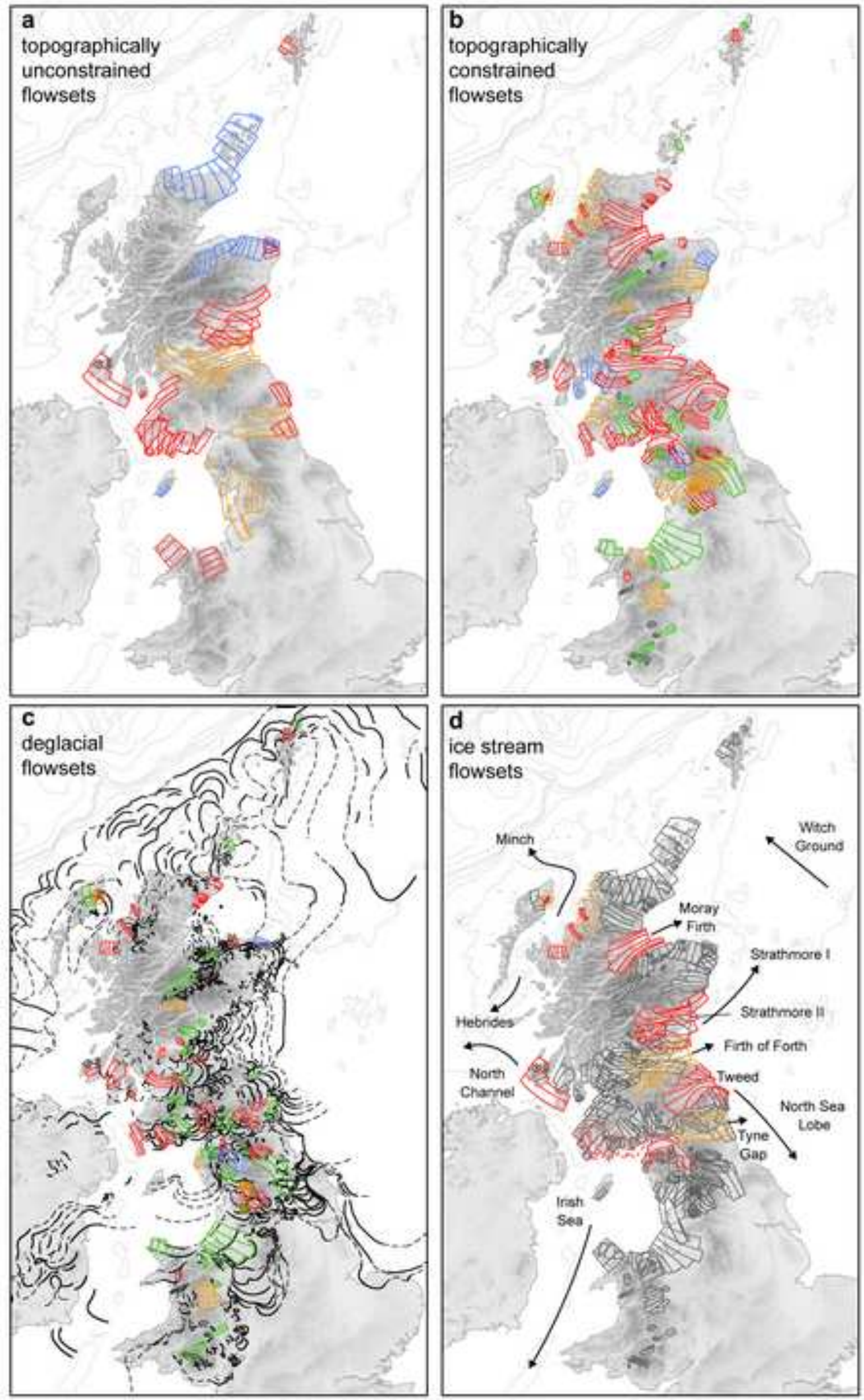

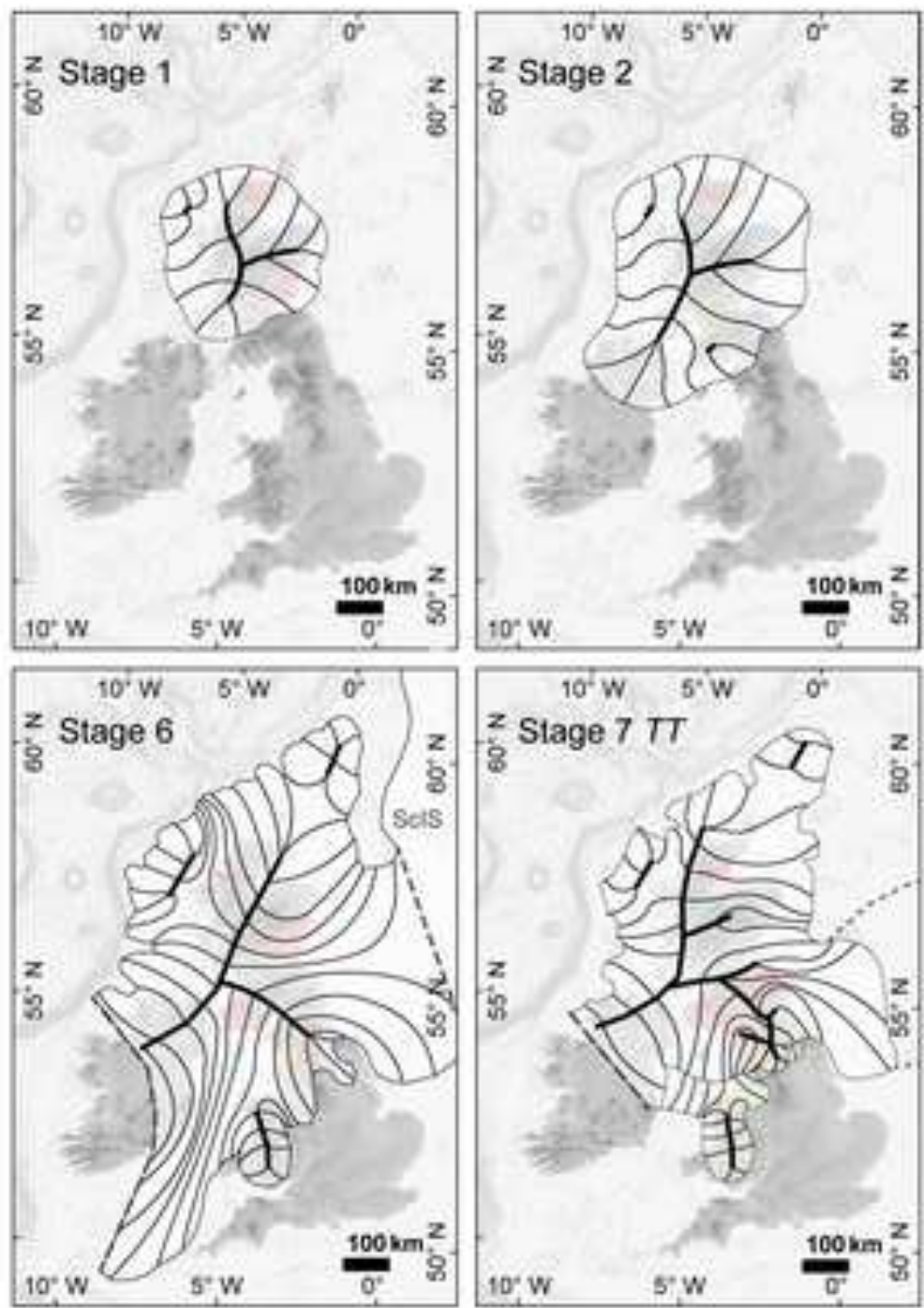
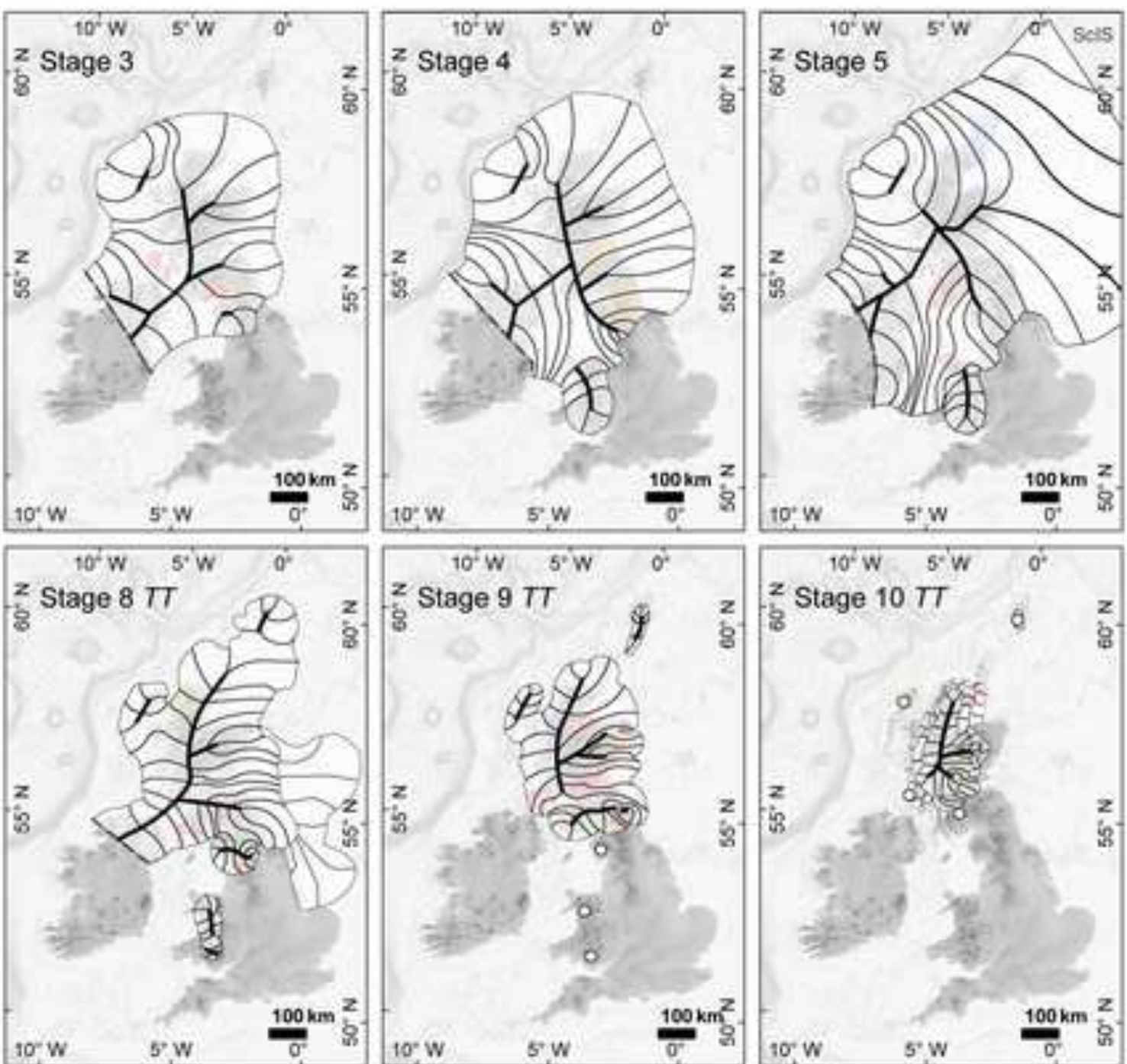
Figure
Click here to download high resolution image
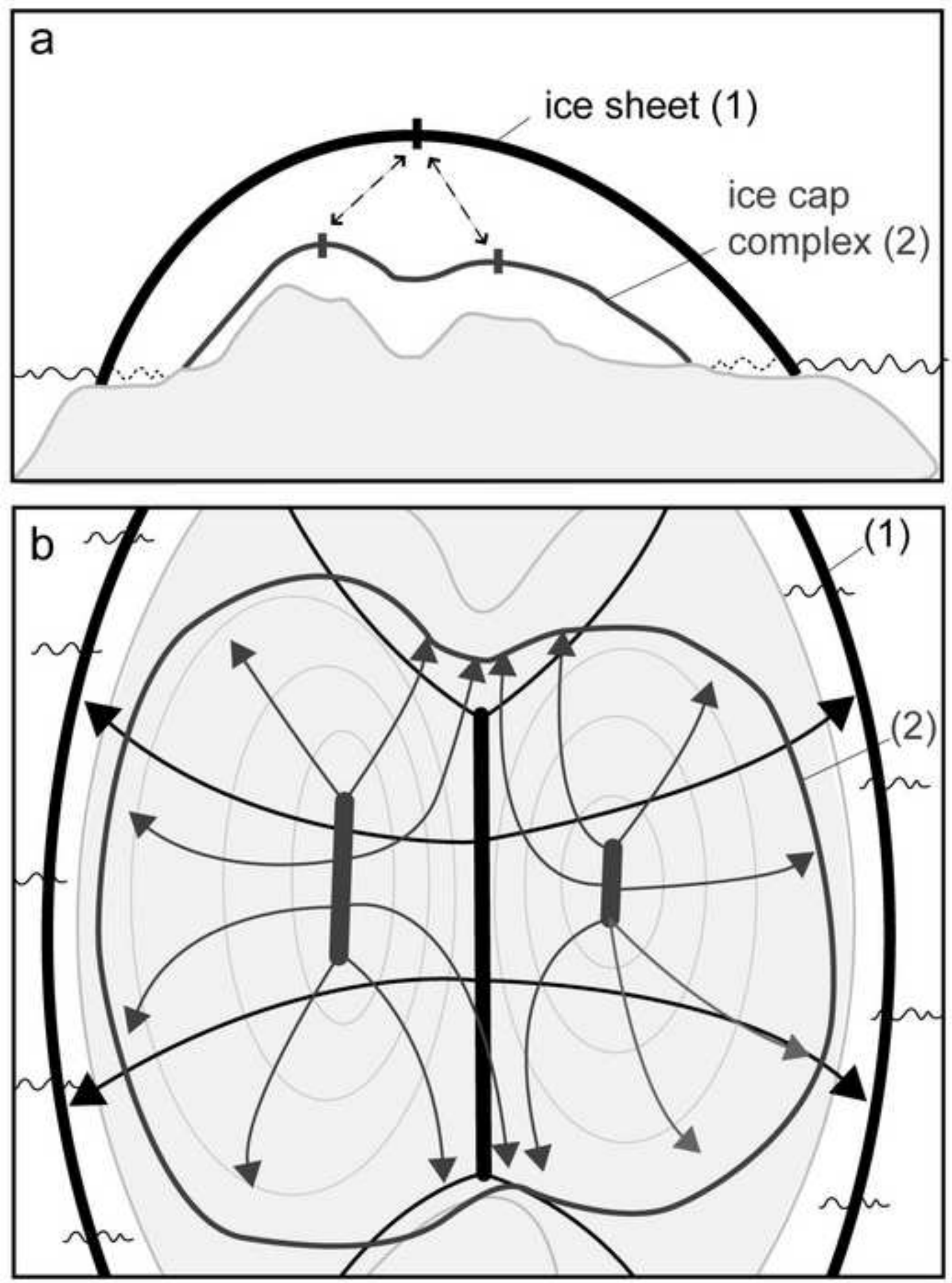
Supplementary Data Figure S1
Click here to download Supplementary Data: FigS1.pdf

Supplementary Data Figure S1
Click here to download Supplementary Data: FigS1.pdf

\author{
df

f

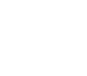

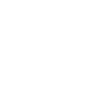

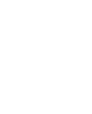

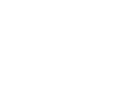

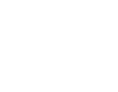

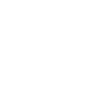

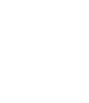

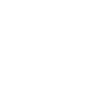
(a)

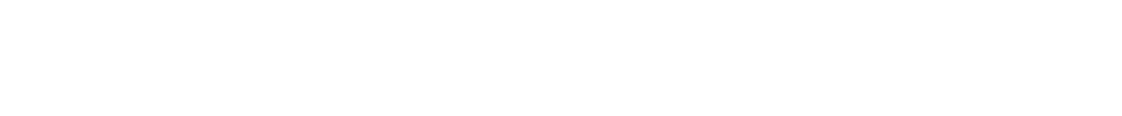
.

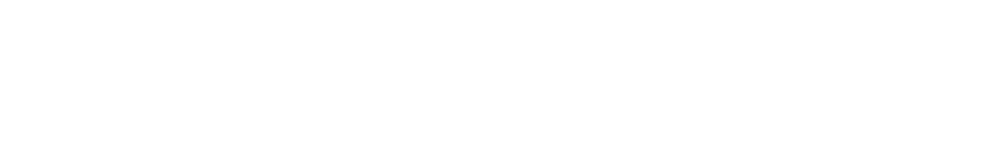
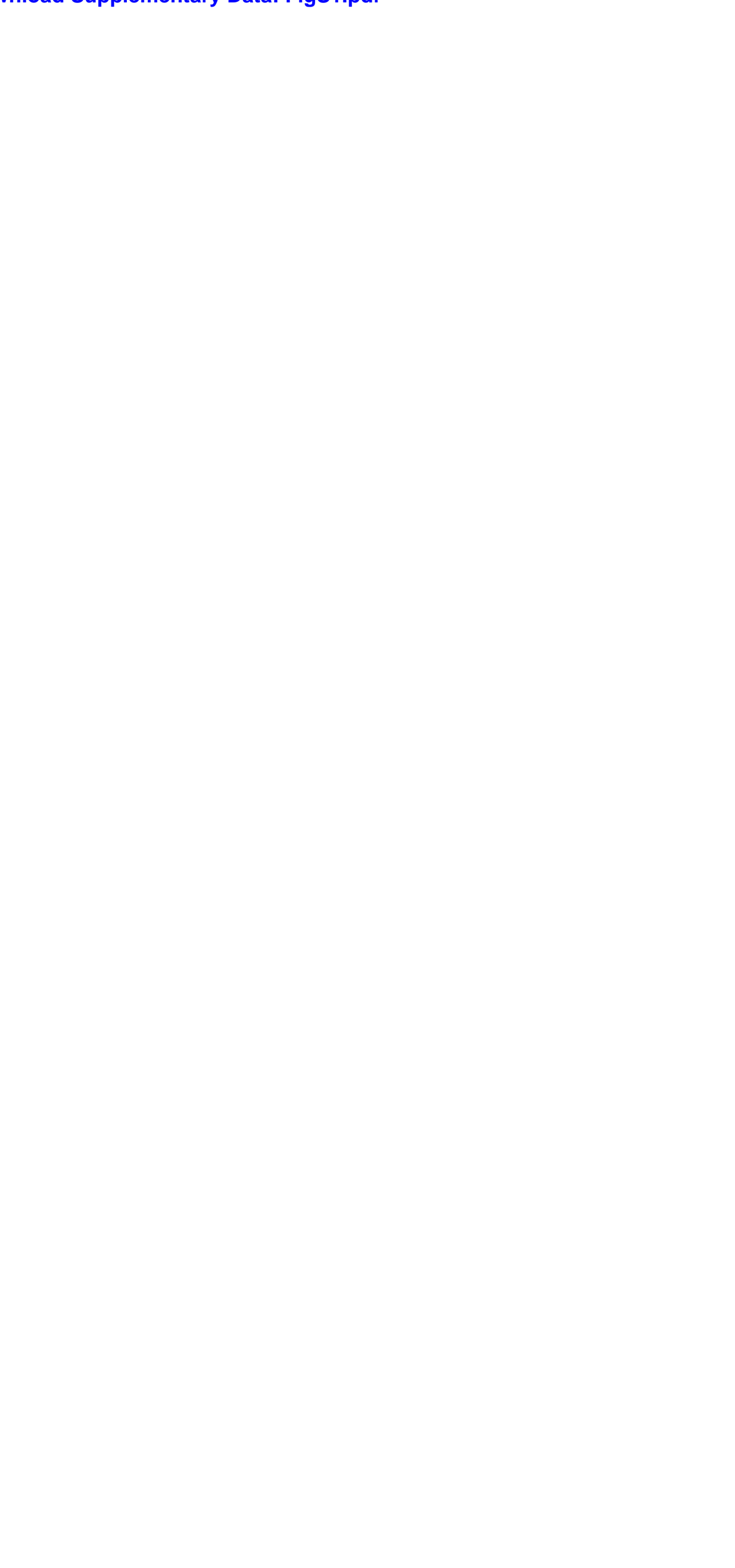
Supplementary Data Table S1
Click here to download Supplementary Data: TableS1.pdf

ff

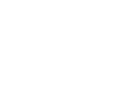

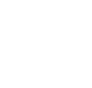

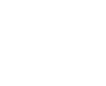

(

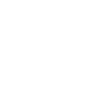

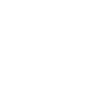

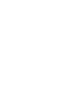

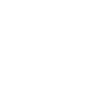

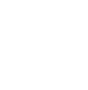

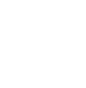

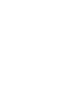

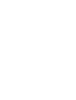

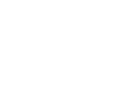

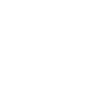

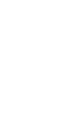
.

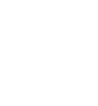

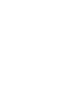

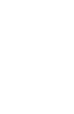

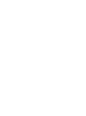

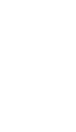

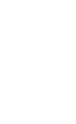
. . .

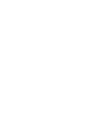

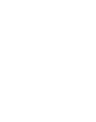

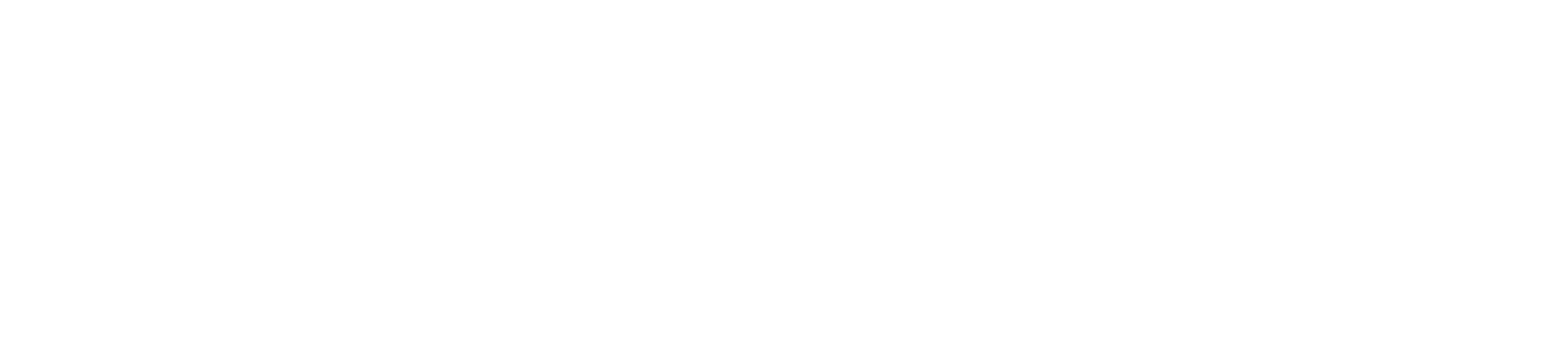

